\title{
Šamanismist ja tšuktši šamaanide ravimisriitustest
}

\begin{abstract}
Ülo Siimets
Teesid: Käesolevas artiklis püütakse vastata küsimustele, kes on šamaan, tuginedes kirjandusele ja autori 1971. aastal Tšuktšimaal elades ja töötades saadud tähelepanekutele. Šamanism on üks tähelepanuköitvaimaid ja levinuimaid religioosseid tavasid, mida praktiseerivad kõige enam Põhja-Siberi ja PõhjaAmeerika põliselanikud. Šamaanid hoiavad kontrolli all oma kehas olevaid vaime ning võivad lahkuda tavaeksistentsist, et rännata või lennata teistesse maailmadesse. Šamaan, kelleks on tavaliselt mees, võib manustada hallutsinogeene rituaalide läbiviimiseks või teadvuse seisundi muutmiseks.

Lõpuks kirjeldan üht raviseanssi, mille viis 1971. aasta septembris läbi minu põhjapõdrakasvatusbrigaadi šamaan Ejgeli, kes ravis tulemuslikult teismelise poisi vigastatud jalga.
\end{abstract}

Märksõnad: nganassaanid, põhjapõdrakarjused, rahvameditsiin, raviseanss, šamanism, transs, tšuktšid

Kindlasti on šamanism, šamaanid ja ravimisriitused sõnad, mis liigutavad iga folkloristikast huvitatut. Nende teemadega on tegeldud läbi sajandite, mistõttu nimetan siin Venemaa arvatavasti esimesi olulisi šamanismiteemalisi väljaandeid nagu etnograaf Viktor Mihhailovski (1864-1904) peateos, 1892. aastal Moskvas Keiserliku Loodusuurijate Seltsi toimetistes ilmunud Шаманство. Сравнительно-этнографические очерки (Šamanism. Võrdlev-etnograafilised kirjeldused), mis tõlgiti kiiresti ka inglise keelde ja mida kasutasid paljud teadlased kogu maailmas, samuti samades toimetistes 1890. aastal ilmunud Nikolai Haruzini Русские лопари (Venemaa saamid) ning N. Agapitovi ja M. Hangalovi 1883. aastal Irkutskis välja antud Матеріалы для изученія Шаманства въ Сибири. Шаманство у Бурятъ Иркутской губерніи (Materjale Siberi šamanismi tundmaõppimiseks. Šamanism Irkutski kubermangu burjaatide seas). Venemaal on šamanismi uurinud ka A. Anohhin, V. Anutšin, Vladimir Bassilov, Vladimir Bogoraz-Tan, Galina Gratšova, Valentina Haritonova, V. Ionov, I. Lopatin, Andrei Popov, Georgi Potanin, Vassili Radlov, 
Lev Sternberg, Pavel Tretjakov, Pavel Šimkevits jpt. Ka mujal maailmas on palju tegeldud šamanismi uurimisega. Nimetagem siinkohal Majorie Balzerit, John Bowkerit, Kai Donnerit, Ray Dunningut, Michael Harnerit, M. Hopperit, Jonathan Horwitzit, Kustaa Fredrik Karjalainenit, Matias Aleksanteri Castréni, Toivo Lehtisalot, Mircea Elidet jt. Eestis on viimastel aastatel šamanismi uurimisega suuremal või vähesemal määral seotud olnud või nende tegemistest kirjutanud Andres Adamson, Aado Lintrop, Lennart Meri, Hendrik Relve, Mikk Sarv, Tõnn Sarv, Ülo Siimets, Triinu Ojamaa jne.

Käesolevas artiklis püütakse vastata küsimusele, kes on šamaan. Kas ta on hullunud inimene, nagu väidavad mitmed autorid, või ravitseja - teadjamees. Ehk on ta nõid? Pakume erinevaid vastuseid küsimusele, kes võib saada šamaaniks. Kas selleks sünnitakse? Kas šamaanil on mingid erilised tundemärgid või kuidas üldse šamaani ära tuntakse? Kas saab iga inimene šamaaniks õppida? Artiklis kasutatakse tšuktši šamaane puudutavas osas sada aastat tagasi Tšuktšimaal töötanud Vladimir Bogoraz-Tani materjale. Samuti on ära toodud Vladivostoki lähedalt eestlaste külast Kamtšatkale suu- ja sõrataudi likvideerima saadetud veterinaararsti Johannes Niggoli mälestusi, kes külastas oma ringreisidel ka Tšuktšimaad ja kirjeldab väga värvikalt seal 20. sajandi algul valitsevat meditsiinitaset.

Ka Tihhon Sjomuškin on oma raamatus Tšukotka kirjeldanud paarkümmend aastat hilisemat olukorda Kaug-Põhjas, kui koos nõukogude võimu saabumisega hakati rajama haiglaid. Kuigi T. Sjomuškin on kirjutanud nõukogude võimu ülistava, propagandistliku raamatu, leiame sealt mõningaid huvitavaid fakte.

Artikli autor viibis ise 20. sajandi kolmandal veerandil Tšuktšimaal ja tähendas oma muljed päevikusse, kust on kirjeldatud mitmeid kohtumisi šamaanidega ja nende poolt läbi viidud raviriitusi ning toodud ära kohalike elanike selleteemalisi jutustusi.

Šamanism on üks tähelepanuköitvaimaid ja levinuimaid religioosseid tavasid, mida praktiseerivad kõige enam Põhja-Siberi ja Põhja-Ameerika põliselanikud. Šamaanid hoiavad kontrolli all oma kehas olevaid vaime ning võivad lahkuda tavaeksistentsist, et rännata või lennata teistesse maailmadesse. Šamaan võib manustada hallutsinogeene rituaalide läbiviimiseks või teadvuse seisundi muutmiseks. Nii siseneb šamaan vaimude ilma. Kurje vaime tuleb kontrolli all hoida või võita, headelt vaimudelt abi paluda. Inimeste maailma tagasi pöördudes on edukas šamaan midagi oma kogukonna heaks teinud. Kui midagi viltu läheb, võib šamaan hulluks minna või isegi surra. Teistest maailmadest omandatud võimete ja teadmistega võib šamaan lauldes, masseerides või taimseid ja maagilisi vahendeid kasutades ravida, tulevikku 
ennustada, tüliküsimusi lahendada, loodusõnnetustega võidelda või vaenlasi rünnata (Bowker 2004: 200). Briti teadlane Ray Dunning kirjutab:

Kõik soome-ugri rahvad praktiseerisid animalistlikku religiooni, mis keskendus šamaani ülemvõimule. Sõna "šamaan" (naissooline vorm "šamanka") tähendab "erutatud" või "tõusnud". See kajastab transilaadset seisundit, millesse nõiad langesid ajal, mil nende hinged usuti rändavat teispoolsuses. Sageli võrreldi šamaani rituaalseid rännakuid redelit või puud mööda ülesse ronimisega. Neid kirjeldati ka lendamas linnuna või tiivulise hobuse seljas (McKenzie \& Prime \& George \& Dunning 2002: 80).

Võõrsõnade leksikonist leiame sõnale šamaan tähenduse, et see sõna on pärit evengi keelest ja tähendab hullunud inimest. Sõnaseletuses lisatakse, et šamaan on arhailiste ühiskondade nõid, kellel ekstaatilises seisundis olevat võime astuda ühendusse vaimudega ja rakendada seda haiguste ravimiseks, õnnetuste vältimiseks, jahiõnne saavutamiseks jne (Vääri \& Kleis \& Silvet 2000: 957).

Viimasel ajal on üle maailma levima hakanud neošamanism. Selle õpetuse järgi võib hea tahtmise korral õppida ja leida tee lapsepõlve loova väe juurde ning seda kasutada ka täiskasvanueas olemise ja elamise tervemaks muutmiseks. Šamaani ehk nõia eesmärgiks ongi olla ise terve ja tuua tervist teistele.

Tuumšamanism (core shamanism) on Michael Harneri poolt eri mandritel ja kultuurides esinevate šamanismipraktikate uurimise tulemusena kasutusele võetud termin. M. Harner avastas, et šamanismi praktiseerimisaladel Põhja- ja Lõuna-Ameerikas, Aafrikas, Põhja-Euroopas, Aasias -, võib täheldada ühtelangevaid tehnikaid. Neist kujunenud võttestiku nimetaski ameerika uurija tuumšamanismiks. Šamaan erineb teistest tervendajatest sellepoolest, et ta kasutab šamaanirännakut, mis on oma olemuselt retk ebatavalisse reaalsusesse.

Michael Harneri õpilane Jonathan Horwitz on loonud Skandinaavia šamaaniuuringute keskuse, kus tegeldakse muu hulgas ka šamanistlike võtete ja tänapäeva psühholoogia ühisosade otsimisega. J. Horwitz on 1990. aastate alguses käinud ka Eestis algkursusi juhendamas (Adamson 2002).

Kahjuks ei oska ma evengi keelt, aga Jonathan Horwitz saab seda tundes sõnast "šamaan" aru teisiti kui eestikeelse võõrsõnade leksikoni koostajad (või nende eeskujud). Ta kirjutab, et

[---] sõna "šamaan" on muutunud new-age’i moesõnaks, mida kasutavad paljud, kuid mõistavad vähesed. Algselt on sõna pärit Siberist evengi 
keelest, otsene tähendus on "see, kes teab." Tänapäeva lääne maailmas arvavad mõned, et šamaan on iga põlisrahvast pärit tervendaja, teiste arvates on selleks iga mõjusa vaatega tugev isiksus. Tegelikult saab määratleda tema tegevuse järgi. Šamaan on lihtsalt inimene, kes muudab tahtlikult oma meeleseisundit, et kõnetada ja reisida teise reaalsusesse väe ja teadmiste järele (Horwitz 2002).

Nagu võime välja lugeda ülaltoodust, usuvad Aafrika asukad endiselt nõiduse väge, eriti haiguste ravimisel. Arvatakse, et kõikidel haigustel on psüühilised või maagilised põhjused, mis lähtuvad sageli kellestki, kes kadestab või vihkab oma ohvrit ja on palunud abi kelleltki, kellel on "kuri silm". Enamikus külades on vähemalt üks teadjamees või -naine, keda Lõuna- ja Kesk-Aafrikas nimetatakse ngangaks ja kelle poole haiguse korral esimesena pöördutakse. Ta kasutab raviks taimede segusid, mis peavad esile kutsuma maagilise efekti, või siis amulette, mis kaitsevad kahjulike mõjude eest. Kui küla šamaanilt abi ei saa, pöördutakse võimaluse korral lääne meditsiini poole (McKenzie \& Prime \& George \& Dunning 2002: 90).

Tänapäeva Eestis ja arvatavasti ka mujal Euroopas pöördutakse esmajärjekorras arsti poole. Kui arstilt abi ei saada, siis otsitakse üles mõni teadjamees või ravitseja. Kuid on ka vastupidiseid juhtumeid.

Michael McKenzie, USA Keuka Kolledži usundiloo abiprofessor on arvamisel, et

[---] tänapäeval on inimesed taas hakanud iidsete tavade poole pöörduma, et nende abil psühholoogilistest kriisidest üle saada. Muistsete kultuuride ettekujutus keha ja hinge vastasmõjust loob silla kõrgtehnoloogilise arstiteaduse edusammude ja vaimu vajaduste vahele. Euroopas ja Põhja-Ameerikas on mindud teadlikult muistsete tavade taastamise teed, et sel moel elustada usku taimede ja loomade pühadusse ning sellese, et loodus on puutumatu (McKenzie 2002: 20).

Valentina Haritonova kirjutab, et viimased 15 aastat on toonud Venemaal kaasa traditsiooniliste religioossete kommete (šamanism, nõidus, posimine jt) taassünni. Nende põhjal on tekkinud ka uusilmingud (neošamanism, uusnõidus) ja juurdunud välismaised šamanismikombed (näiteks Michel Harneri eksperimentaalšamanism). On loodud mitmesuguseid praktilise maagiaga tegelevad rühmad (parapsühholoogia, biolokatsioon, ufoloogia), rahvaarstide ühendused, šamaanikodud. Šamanismi moderniseerimise protsess Venemaal väljendub eri traditsioonide esindajate konsolideerumise püüdes. Näiteks Moskva lähistel korraldatakse perioodiliselt vene, hakassi ja tõva šamaanide ning neošamaanide ühiseid seminare-loitsimisi (sealhulgas talvise ja suvise 
pööripäeva rituaale); seal võivad osaleda ka M. Harneri metoodika järgijad, budistlike usuühenduste esindajad jne (Haritonova 2004: 105-106, 109-110).

Tiina Sarve küsimustele, kes on šamaan ja kas šamaaniks saab õppida, vastab etnoloog, Georgetowni Ülikooli professor Marjorie Mandelstam Balzer, et nii seda kui ka teist.

Kõige olulisem on seejuures võime saata signaal hingedele.

Inimesed, kes on tõelised šamaanid, põevad sageli, eriti noores eas. Selle kohta on Sahha Vabariigis (endine Jakuutia) eriline sõna etinõ - see on piinatus [---] Need inimesed peavad tundma vajadust aidata teisi. Kui nad on selleks valmis, algabki nende šamaaniks saamise tee (Sarv 2000).

Küsimusele, kas on võimalik vahet teha tõelisel šamaanil ja šarlatanil, vastab M. Mandelstam Balzer:

See on tõsine küsimus. Šamaane on rohkesti. Näiteks Sahha Vabariigis läks šamaanlus üheksakümnendate aastate alguses väga moodi. Ühtäkki ilmus väga arvukalt inimesi, kes pretenteerisid sellele, et nad on šamaanid. Nü̈̈d on asi veidi vaibunud.

Mina pean tõelisteks šamaanideks neid, kes tõesti on kannatanud, kel on see eriline märk, etinõ. Teiseks peavad nad olema head inimesed. Nad ei tohi olla ahned ega võtta abistamise eest raha. Nendele on kõige tähtsam aidata inimesi.

Kui te olete patsient, võite isegi intuitiivselt tunda, et tõeline šamaan suudab teid aidata. Tal on eriline energia ja teadmised [---] šamaan peab tundma taimi ja óppima palju muid asju. See on endise Nõukogude Liidu alal võrdlemisi keeruline, sest pärast nõukogude repressioone, ei saa olla kuigi palju inimesi, kes saaksid öelda, et nad óppisid tunnustatud šamaanide juures (Sarv 2000).

Neošamanismi kohta ütleb M. Mandelstam Balzer:

Alguses olin ma neošamanismi suhtes natukene skeptiline. Teadsin, et neošamanismi esindajail on oma seansid, milleks nad tulevad kolmeks päevaks kokku ja sõidavad siis jälle koju ning muutuvad bürokraatideks.

Selgus, et paljud neist tegelevad asjaga palju tõsisemalt, kui üldine stereotü̈̈p aimata laseb. Paljud ei tegele šamanismiga ainult enda tarbeks, vaid abistavad ka teisi inimesi. See on väär arusaam, nagu oleks nad kõik individualistid (Sarv 2000). 
Samas tuuakse ära ka praeguse Tartu Ülikooli etnoloogiaprofessori Art Leete arvamus:

Maailmas on kaht tü̈̈pi šamanismi. Esiteks on traditsiooniline šamanism, mis eksisteerib tuhandeid aastaid ja on oma tegelikes vormides säilinud ainult väikestes, suhteliselt eraldatud ühiskondades. Selles suhtes võime öelda, et šamanism on väljasurev nähtus.

Teiseks, viimasel ajal on üle maailma levinud šamanismi uued vormid neošamanismi nime all.

Väikeste kogukondade šamaanid on traditsioonide kandjad, neošamanism on rohkem isiklik (Leete 2000).

Kölni etnoloogiainstituudi juhataja ja Saksa Etnoloogiaseltsi esinaine Ulla Johansen ütleb:

Šamaanid on väga kreatiivsed, loovad. Neil on võime transsi minna. Nad on suurepärased psühhosomaatiliste haiguste ravitsejad ja pakuvad huvi ka tänapäeva psühholoogidele.

Šamaanid on samuti poeedid, kirjanikud, kunstnikud ja muusikud. Seega pakuvad nad lisaks puhtteaduslikule huvile ka palju praktiliselt kasulikku (Johansen 2000).

Vigala Sass on öelnud eravestluses, et ka meie inimeste haigustel on põhiliselt psüühilised põhjused ning tema juurde jõuavad inimesed tihti liiga hilja, kui ta ei saa neid enam aidata. Ka tema ravib paljude ravimtaimede, nende segude, oma kogemuste ja tarkusega. Šamaani, teadjamehe ja nõia tähenduse kohta ütles Vigala Sass, et igaüks on erineva tähendusega. Šamaanid on erilised inimesed ja selleks sünnitakse. Ka siis ei olda kohe veel šamaanid, vaid selleks saamiseks tuleb aastaid õppida ja töötada tõelise šamaani kõrval. Vahel kulub selleks mitukümmend aastat, et sind pühendataks kõikidesse saladustesse. Neošamanismi kohta arvas ta, et see on umbes sama nagu praegu levima hakanud kristlike sugemetega maausk.

Tšuktšimaal on olemas nii šamaanid (enenõlin) kui ka teadjamehed (giulet-remkkõn). Šamaan on võimsam ja seega tähtsam tegelane kui teadjamees. Peale selle oli igas jarangas inimene, kes oli võimeline loitsima.

Vladimir Bogoraz-Tan kirjutab:

Igal perekonnal on üks või mitu bubinit, millel kõik pereliikmed viljelevad šamanistlikku tegevust. Nad põristavad trummi ja loitsivad. Sellistel juhtudel pü̈̈ab peaaegu alati keegi pereliikmetest šamanist- 
like võtetega luua ühendust "vaimudega". Mõnikord pü̈̈avad nad ennustada tulevikku, kuid sellele ei pöörata erilist tähelepanu (Bogoraz-Tan 1939: 136-137).

Samas kirjutab ta, et kui selline perekondlik šamanism võib toimuda päeval jaranga üldruumis, siis tõelised šamaanid tegutsevad jaranga pimedas sisetelgis ja tavaliselt öösel (Bogoraz-Tan 1939: 105).

Pean märkima, et 1971. aastal oli aeg edasi läinud, perekondliku šamanismiga tegeldi ka väljaspool jarangat ning šamaan võis viia oma riitusi läbi jaranga üldruumis.

Ka Tihhon Sjomuškin toob välja tšuktši perekondliku šamanismi. Temalt leiame lause:

Ulvurgõn oli küll asulanõukogu esimees, kuid see ei takistanud tal veidi šamaanitseda. See oli perekondlik šamaanitsemine. Igas jarangas rippus trumm ja igaüks šamaanitses "oma tarbeks" (Sjomuškin 1953: 67).

Mis puutub šamaanidesse, siis ühtib minu arvamus Vigala Sassi omaga. Šamaan on eriline inimene. Ta on selleks sündinud ja õppimine võib viia ta mingile tasemele, aga iseõppijal on tippu jõuda raske.

Kohtasin Kaug-Põhjas olles mõlemat liiki riituste läbiviijaid, nii teadjamehi kui ka šamaane. Selgituseks ütlen, et ma tegin kaasa 6000-kilomeetrise rännaku tšuktšidest põhjapõdrakarjustega. Karjas oli kuus meest - viis tšuktši ja mina. Töötasin põhiliselt päevases vahetuses, kus minu kaaslaseks oli Ejgeli. Tema oli meie põdrakasvatusbrigaadi šamaan - riituste läbiviija. Ta oli kindlasti parem ja teadlikum kui tavaline giulet-remkkõn, samas ei olnud tema vaade nii terav kui Vaegi šamaanil. Vähemalt meie pilkude ristumisel ei tekkinud nende vahel sähvakaid. Tavaelus ongi väga raske eristada, kuhu riituste läbiviijat liigitada.

Vaegi külast radiaalselt mitmes, õigemini üheksas suunas paiknesid 300$500 \mathrm{~km}$ kaugusel põdrakasvatusbrigaadid. Sealseteks keskusteks olid jarangadest (põdranahkadest elamu) külad. Igas külas oli 7-12 jarangat. Jarangakülade juurest said alguse põdrakarjade toitumisretked karjamaadele ning teatud aja järel jõudis põdrakari jarangade juurde tagasi. Karjas olles ja karjaga ringi liikudes, kui põhjapõdrakari ei olnud jarangade läheduses, magasid karjused telkides või lausa lahtise taeva all. Peaaegu kõikidel tšuktši põhjapõdrakasvatusbrigaadidel olid haldjate ja vaimudega suhtlejateks oma šamaanid või teadjamehed, keda nimetati giulet-remkkõn. Need mehed elasid põhiliselt jarangakülades. Kui paljudes jarangakülades elasid šamaanid, selle 
kohta ma teavet ei saanud. Minu kaaslase Eeriku põhjapõdrakasvatusbrigaadis, mis oli ühismajandi Tee Kommunismile (Put $k$ Kommunismu) parimaid, vähemalt Eeriku jutu järgi, selline mees puudus. Samas tean, et peale meie brigaadi šamaani Ejgeli elas üks šamaan Vaegi külas.

Kirjeldan meie brigaadi šamaani. Ejgeli oli lühikest kasvu, umbes $150 \mathrm{~cm}$ pikkune mongoliidsete näojoonte ja tumedate pilusilmadega mees. Tema silmad vaatasid natukene kõõrdi. Samas oli tema ühe silma pilk terav, läbitungiv. Tundus, et ta vaatas sinust justkui läbi, samal ajal kui teine silm jälgis kõrvaltoimuvat. Tavaliselt me vesteldes teineteisele eriti silma ei vaadanud. Ta oli jässakas, tugeva pika ülakeha ja lühikeste kõverate jalgadega mees. Tegelikult olid enamikul tšuktšidel lühikesed kõverad jalad. Arutasime hiljem Eerikuga, et ju oli selline kõverjalgsus geneetilise arengu tulemus. Tundras on parem ja lihtsam liikuda, kui mättad kõverate jalgade vahelt läbi libisevad. Sirgete jalgadega inimesed, nagu eurooplased, peavad oma jalgu väga kõrgele tõstma, et mätastest üle saada. Ejgeli karusnahksele kuhfljankale oli vihma vastu kaitseks peale tõmmatud presentürp. Jalas olid tal vees mittemärguvast kuldkollasest hülgenahast kaunistustega torbased (nahksaapad). Pea oli kaetud karusnahkse kapuutsiga, millele oli peale tõmmatud presentkapuuts.

Ejgelil oli alati kaasas lühikene oda, mis meenutas jahioda. Algul arvasingi, et see on jahioda. Hiljem pühendati mind saladusesse, et see on rituaaloda. See oda oli väga vana, kuid täpset vanust ei teadnud keegi. Oda pärandati mehele - perest väljavalitud pojale - ja nii olevat see toimunud põlvest põlve. Vahel oli selleks väljavalituks pere vanim, mõnikord mõni teine poeg. Valiku aluseks olevat inimese võime hingedega suhelda. Nagu öeldud, pidi igas põdrakarjuse peres või vähemalt igas jarangakülas olema vähemalt üks selline inimene. Mõnes laagris olevat selliseid inimesi mitu.

Tšuktšid ise rääkisid, et niisugused väljavalitud lapsed on äratuntavad juba varakult, sest nad ei vaata rääkides vestluskaaslasele otsa, vaid vaatavad midagi, mis asub rääkijast tagapool või üleval. Nende laste pilk pidi erinema teiste laste pilkudest ja mõnede laste pilk pidi otsekui sädelema. Eriti terav pidi olema pilk nendel lastel, kellest saavad hiljem päris šamaanid, sest nendel on vaja oma töö tõttu näha just hingi ja vaime. Šamaanid pidid hingede nägemisega hakkama saama isegi pimeduses.

Ejgeli oda tera oli kaunistatud maagiliste ornamentidega. Paljud märgid olid aastatega sellelt maha kulunud. Tšuktši jutu järgi olid tera peale kirjutatud sõnad vanas tšuktši keeles. Selline tähestik olevat Tšuktšimaal olnud enne venelaste tulekut. Venelased olevat viinud tšuktši keele üle kirillitsale, et ise aru saada, mis kirjutatud, sest ega nad viitsi teiste keeli selgeks õppida. (Nõukogudeaegne entsüklopeedia väidab, et tšuktšidel puudus enne 
venelaste tulekut oma tähestik ja nad said oma kirjakeele alles 1931. aastal, kuid Lennart Meri raamatu Virmaliste väraval järgi oli tšuktši tähestiku looja Vladimir Bogoraz-Tan).

Tartu Ülikooli filoloogiatudengitele räägitakse loengus, et mõningatel põhjarahvastel oli varem, enne nõukogude võimu kehtestamist oma tähestik, näiteks tuuakse komi keel, millel oli oma tähestik ja kirjakeel. Vene misjonär Permi Stefan kasutas seda pühakirja ja muude tekstide kirjutamiseks ja ülesmärkimiseks. Hiljem on Moskva ikoonimeistrid pühapiltidele nimesid kirjutanud samas tähestikus. Veel hiljem pandi see tähestik kirikujuhtide poolt kirikuvande ja keelu alla, selles kirjas kirjutatud raamatud põletati. Tähestiku aluseks oli olnud põhjairaani tähestik. Võibolla oli oma kiri ka teistel põhjarahvastel. Kerkib ka küsimus, kuidas said tšuktšid kirja omamata saata Katariina II sünnipäevaks tšuktšikeelse tervituse, mis Peterburis tõlgiti ja ette loeti? See küsimus jääb vastuseta.

Tavaliselt oli rituaalse oda tera kaetud narmastega kaunistatud nahktupega. Narmad olid lõigatud ühest naharibast, nii et nad moodustasid inimfiguurid, kes olid ühtlasi kaitsevaimudeks. Selleks oli nahariba lõigatud neljaks narmaks ja narmaste otsa seotud sõlmed. Odatupe külge kinnitatud ülemine osa moodustas pea. Äärmised narmad olid lühemad, olles käteks, keskmised aga pikemad, olles jalgadeks. Sellist kaitsevaimu kutsuti kipuriks. Neid kujukesi kasutati kaitsevaimudena mitmes kohas. Näiteks jarangade uste lähedal, magamisasemete - pologide - juures. Tähelepanelikul vaatlemisel oli neid märgata isegi riietusesemete kaunistamisel.

Paljudel meestel olid talvel peas kahe terava tipuga mütsid, mille teravad nurgad olid nagu koerakõrvad. Koerakõrvade otsas rippusid kipurid, mille valmistamisel oli kasutatud sõlmede asemel naharibade otsa õmmeldud nööpe. Meestel oli tavaliselt vööl ka nahkkotikene, mille sees oli kaheharulisest puust kipur.

Oda külge oli terast allapoole kinnitatud kuljus, mis liikumisel pidevalt kõlises. Kuljus pidi oma helinaga peletama halba vaimu ketljat. Oda vabastati

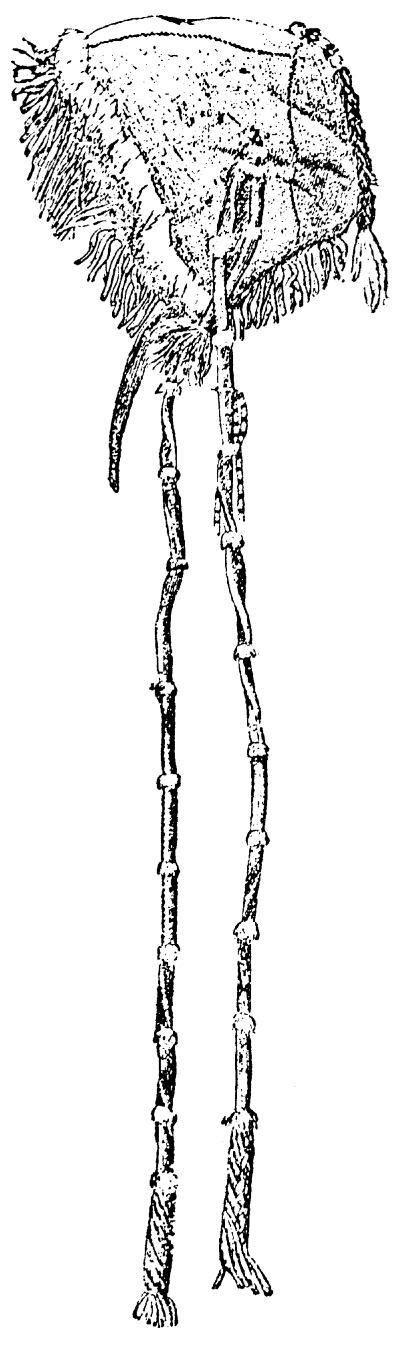

Joonis 1. Müts (Bogoraz-Tan 1939). 
tupest ainult rituaalsete ohverduste ajal. Muul ajal oli ta tupes ja mees kandis teda kogu aeg endaga kaasas.

Ejgelil oli alati kaasas hülgenahkne seljakott. Tema vööl rippusid nuga, lumelamba sarvest voolitud luulusikas, kruus, nahkkott padrunitega, tubakakott koos tikkude, tulekivi ja niidi-nõelaga ning veel mõned nahkkotikesed. Vihma ajal oli üle kõige tõmmatud plastikkile. Šamaani kõrvadesse olid tehtud augud, millest olid läbi torgatud heinakõrred.

V. Bogoraz-Tan kirjeldab, et enda eristamiseks teistest kasutavad šamaanid naiselikke kaunistuselemente. Mõeldes Ejgelile, see nii ka oli.

"Augud on selleks, et saaksin kõrvarõngaid kõrva riputada, kui tahan ilus välja näha. Ilma kõrteta kasvavad augud kinni," oli mees vastanud küsimusele, miks tal kõrred kõrvas on.

Teised karjused irvitasid seda kuuldes ja ütlesid, et Ejgeli riputab kuljused kõrva, kui ta tantsima läheb (Siimets 1999a).

Tegelikult olidki tal augud kõrvas selleks, et näiteks jarangade juures läbi viidavatel riitustel väikseid kellukesi kõrvas kanda, mis siis tantsides tilisesid (pikemalt 1999a: 144-146).

V. Bogoraz-Tan oli arvamusel, et Tšukotka šamanism ei ole veel saavutanud seda taset, et seal oleksid spetsiaalsed bubinid (tšuktši k trummid), riietus ja kõik sinna juurde kuuluv. Tšuktši šamaan kasutab tavalist perekonnatrummi või teeb endale samasuguse üldkasutatava kujuga bubini. Sellist trummi kasutatakse kõigi pereliikmete poolt kõikidel pühadel. Ka ei ole

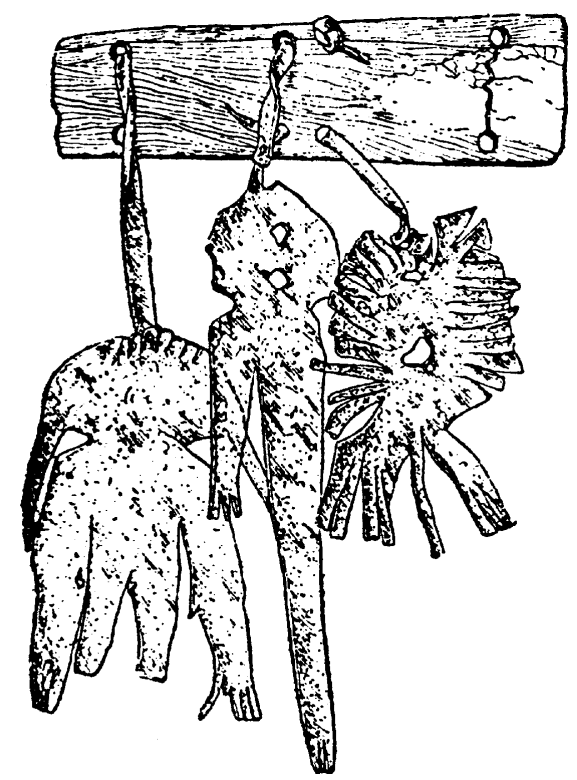
nende riietusel erilisi kaunistusi ega narmaid, nagu need on tunguusidel ja jukagiiridel. Tšuktši šamaanid viisid riitusi põhiliselt läbi pologis (jaranga sisetelgis) täielikus pimeduses ja seetõttu ei olnud nende välimusel erilist tähtsust. Polog oli tavaliselt palav ja umbne ning seal tuleb erilise riietuse selgatõmbamise asemel hoopis lahti riietuda või kui šamaaniks

Joonis 2. Šamaani abivaimudega ripats (Bogoraz-Tan 1939). 
Joonis 3. Šamaani särk (BogorazTan 1939).

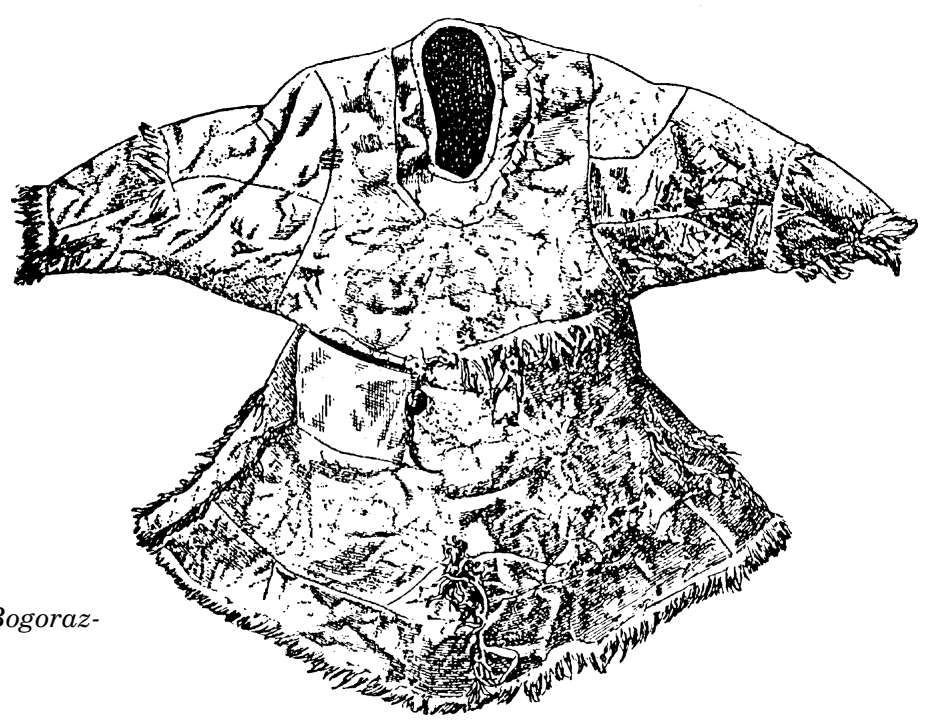

oli naine, siis viskas ta seljast oma karvase riietuse ülemise osa. Samasugune oli olukord Aasia eskimote juures.

Šamaanlikel hingedel on mõnikord kalduvus märgistada nende poolt väljavalituid eriliste tundemärkidega, et eristada neid tavainimestest. See puudutab ainult meesterahvaid. Niipalju kui V. Bogoraz-Tanile teada, ei olnud tšuktšide ega nende naaberrahvaste naisšamaanidel väliseid tundemärke, mis eristaksid neid tavainimestest. Vahel erines tšuktši šamaani rüü tavalise mehe riietusest selle poolest, et nad kasutasid meeste kufljankade kaunistamiseks valgeid narmasääri. Tavaliselt oli selline krae naisterõivastel. Samuti olid narmaskaunistustega käised ja kõik õmblused. Kui tšuktši kufljankade naha karvane pool on pööratud väljapoole, siis ühel V. Bogoraz-Tani nähtud kufljankal oli karvane külg pööratud sissepoole. Kufljanka keskele oli kinnitatud südamekujuline talisman - tetktju (elujõud) ja selle kõrvale oli õmmeldud šamaani abistajahinge kuju - rekke $\eta$ (Bogoraz-Tan 1939: 136-137).

Olin tšuktšide juures umbes seitsekümmend aastat hiljem ja siis oli šamaanil juba eriline rõivastus. Muidugi mitte väga eriline, aga natukene teistmoodi ikka.

Kuidas Vaegi šamaan välja näeb? Küsisin seda kohalikult tšuktši kooliõpetajalt Niinalt, kes vastas:

Noh, tema tunned kohe ära. Tal on peas loomade peanahkadest tehtud müts. Jänesekõrvade otsas rippuvad kuljused. Jalas on tal koeraküünistega kaunistatud hõbedased torbased. Kõndides jäävad suured koerajäljed lumele. Mitte keegi teine ei oska nahka nii parkida. Kui 
talle otsa vaatad, siis löövad ta silmad välku. Kui teda näed, siis ära jä̈̈ talle kauaks otsa vaatama, muidu sattud tema mõju alla.

Mõni aeg hiljem kohtasin külaservas šamaani ja ta nägi välja täpselt nii, nagu Niina oli kirjeldanud. Lisada võib, et kuna ta oli naisterahvas, oli temalgi nägu tätoveeritud. Talle otsa vaadates tekkis mul tunne, nagu oleksin saanud elektrilöögi. Mul oli mulje, nagu oleks minu ja šamaani silmade vahel tekkinud elektrilahendus. Sellepärast siis tüdrukud ütlesidki, et šamaanil lööb silmist välku. Ma ei suutnud või õigemini ei tahtnud talle pikalt otsa vahtida, sest tüdrukute jutt oli tekitanud isegi minus natuke kõhedust või koguni hirmu. Tüdrukute jutu järgi oli šamaan võimeline oma pilguga hüpnotiseerima ja sellepärast ei tohtivat talle pikalt otsa vaadata. Ta olevat hüpnotiseerinud ära Niina mehe, kes enda selles uimas maha lasi (ka meid ähvardati algul vaimudele ohverda - vt Siimets 1999b).

Šamaan elas küla kõige kaugemas servas põdranahkadest jarangas. Rohkem jarangasid selles külas ei olnud - teised inimesed elasid palkmajades. Et elekter pidada šamaani jõudu vähendama, olevat ta keeldunud puumajja kolimast ja elektrit oma elamises kasutamast. Aegajalt oli küla servast šamaani jarangast kuulda bubini põrinat - siis, kui šamaan inimesi ravis või tegeles muude riitustega.

Ühel täiskuuõhtul olime õues ja vaatasime virmaliste sähvimist. Kuuldes kauget bubini kõla, palusime tüdrukuid viia meid šamaanile külla. Tüdrukud nõustusid.

Kergitades jaranga sisenemisava katvat nahka, nägime lõkkevalguses põrandal lebavat inimest. Teisel pool lõket hüples bubinit mängiv šamaan üles ja alla. Ta oli ekstaasis ega märganud meie tulekut. Aeg-ajalt sooritas ta õhus ligi meetrikõrgusi hüppeid, samal ajal põhjapõdravasika sääreluuga trummi tagudes. Lõkke ees lamas keegi liikumatult. Tagaseina ääres olid istet võtnud mingid inimesed.

Kui Niina küsis, et kas võime lõkke äärde istuda, katkestas šamaan oma tegevuse ja meid tabas hirmuäratav kriiskav tšuktšikeelne sõimulaine. See pidi olema midagi hirmsat, sest tüdrukud kangestusid ja põgenesid meid käistest kaasa kiskudes (vt pikemalt Siimets 1999b).

Ka hiljem püüdsime tuttavate tüdrukute kaudu šamaaniga kohtuda, aga nad ei nõustunud meid kokku viima. Ju oli tema kriiskav sõim nad ära kohutanud. Põhjapõdrakarjas olles pühitses kohalik šamaan Ejgeli meid noore põdra püha ajal ohvripõdra verega, mis muutis kohalike elanike suhtumist meisse. Kui külla naasesime, tervitasid kõik vastutulijad meid väga viisakalt ja tundsid huvi, kuidas karjas läks jne. Ka šamaani arvamus meist muutus. Kui varem olime tanhgid (venelaste halvustav nimetus) või yankid, siis nüüd 
kuulusime me cawcude hulka. Tüdrukud kohtasid Vaegis šamaani, kes oli nõus meiega oma jarangas kohtuma, kuid kahjuks läks teisiti. Paar päeva pärast tsivilisatsiooniga kohtumist nakatusime kahjuks mõlemad Eerikuga mingisse tundmatusse viirusesse. Palavik kerkis üle 40 kraadi. Suure vaevaga saime lennukile ja sõitsime tagasi Eestisse. Vaegi šamaaniga kohtumise ärajäämisest on muidugi kahju.

Mõningane sarnasus oli Ejgelil kirjelduse järgi nganassaan Tubjakuga (vt Lintrop 1996), kuigi Ejgeli oli noorem. Samas olid nad mõlemad erilise tunnusmärgiga ja n-ö väljavalitud.

Nganassaanide tuntuimaks šamaanidünastiaks olid Kosterkinid (vt ka Ojamaa 1998), algse nganassaanikeelse nimega Ngamtu-suo. Selle igipõlise šamaanisuguvõsa üheks vanimaks eelkäijaks olnud pärimuste järgi naine nimega Neiming, kes saanud lapse Kotkas-jumalaga. Väga kuulsaks selle šamaanisoo järglaseks tõusis mees nimega Djuhhade. Kolmveerand sajandit tagasi tegutsenud legendaarse šamaani kohta on rohkesti täpseid üleskirjutisi jäädvustanud teenekas antropoloog Andrei Popov. Seejärel tõusis šamaaniks Djuhhade poeg Tubjaku (1921-1989), tundrainimesele kohaselt jässaka keha kohta lühikesevõitu jalgadega mees. Ta oli enesekindel, läbitungiva pilgu ja väärika madala häälega mees. Argijutuajamistel osavõtliku ja mahedapoolse olekuga mees muutus rituaalide ajaks rangeks ja võimukaks. Oma šamaaniks saamise kohta on ta kõnelnud, et on sündinud "särgis". "Särgi" tunnuseks oli "nööp" ehk sünnimärk rinnaesisel, mis jäigi selgesti nähtavaks. Kui kaaskondlased vastsündinud Tubjaku märki nägid, olnud neile selge, et just sellest Djuhhade pojast saab tulevikus šamaan. 1940. aastate lõpus istus mees šamanismi harrastamise pärast vanglas, kuid jätkas pärast vabanemist oma endist tegevust (Relve 2004: 45).

Seega olid mõlemad mehed vaimude poolt nendega suhtlemiseks välja valitud.

Ejgeli teadis väga paljusid lausumisi ja manamisi. Olen kirjeldanud, kuidas mees raevunud karu, kes kahel käpal temast viie meetri kaugusel püsti seisis, sõnade abil taltsutas. Pärast uurisin tšuktšilt, mida too karule oli rääkinud. Ejgeli seletas mulle asja ja lisas, et kui oleksin sama juttu rääkinud tanhgide või eesti keeles, oleks metsloom mu nahka pannud, sest eriti tanhgide keelt karud ei kannata. Metsarahvaga on alati võimalik ära leppida, sest karud on ju loomanahka riietatud inimesed. Nad on nagu šamaanid, kes juba kaugelt mõistavad inimeste kavatsusi. Nendest ei tohi halvasti kõnelda, sest muidu hakkavad nad tegema karjale kurja. Ta keelas ka põtrade vandumise ja nende peale karjumise: "Susi neid söögu", sest sellega toob põdrakarjale tohutu needuse kaela. Nimelt olevat halvad vaimud ketljad 
või kelid võimelised ennast huntidesse peitma ja sellise sõnumisega antakse kari kelide meelevalda (pikemalt vt Siimets 1999a).

Jarangades elasid põhjapõdrakarjuste naised, lapsed ja isad-emad. Puumajadest külla ei soovinud enamik põdrakasvatajate sugulastest kolida. Tšuktšide hulgas oli inimesi, kes ei olnud elu jooksul näinud puust maju, rääkimata saunast. Vaegis oli küll saun olemas, aga seda kasutati ainult suvel, sest talvel ei suudetud hoonet tšuktšide arvates piisavalt soojaks kütta. Selle aja jooksul, mil meie Vaegis viibisime, ei õnnestunud meil sauna pääseda. Kes seal üldse käisid, jäi meile teadmata, sest tšuktšide rahvatarkus oli: "Kui mustus küpseks saab, siis kukub ta ise maha."

Peaaegu samaviisi suhtuti ka haiglasse, kus käisid ravil venelased ja teised läänest tulnud, kuid tšuktšid sattusid harva. Isegi lapsed sünnitati enamasti jarangades, kus sünnitajaid abistasid vanad naised.

Tšuktšimaal viibis 20. sajandi algul eestlane Johannes Niggol, kelle kirjelduste vahendusel saame pildi tolleaegsest meditsiinikorraldusest, nii nagu ta kuulis ja nägi oma sõitudel Kamtšatkalt Petropavlovskist Gišisse ja Markovosse 1911. aastal. Reisi eesmärgiks oli tutvumine teelejäävate külade eluoluga ja vajadusel loomadele ning inimestele arstiabi osutamine. Kirjutise põhjal oli arstiabi Kamtšatkal ja Tšukotkal väga viletsal tasemel ja J. Niggol mõned kirjeldused haigustest ja nende ravimisest on üsna kohutavad.

Tuberkuloosi ei ole ma kunagi neil näinud, küll aga sü̈̈filist, ja sedagi ainult poolkolijail Pentšina lahe ääres. Poolkolijad on need paiksed, kel elukoha ligidal on olemas ka oma põdrakari. See hulgas leidub paiksete hulgas väga palju haigeid. Harjušova külas ei leidnud ma näiteks mitte ühtegi maja, kus ei olnud mõni sü̈̈ilisehaige. Süüfilise vorm on siin hereditaarne (päritud) suurte lahtiste haavadega.

Ma kohtasin kord tundras üht põdrakarja omanikku, kel kuklas oli suur haav, millest välja paistsid viie kaelalüli püstharud. Ja see mees käis väljas ja jahil, nagu poleks tal midagi viga. Kamtšatka orus nägin 50-aastast naist, kelle näoluud olid sü̈̈filisest nii moonutatud, et silmad ei olnud enam mitte ees, vaid külgedel nii kui lehmal. Kui ta rääkis, lõi ta keel välja august, kus enne oli nina ja ülemine mokk. Ta palus rohtu, et terveks saada (Niggol 1937: 34).

Rändkarjakasvatajate tervis oli tunduvalt parem. Nendel ei olnud otsest kokkupuudet meremeestega, keda võis pidada süüfilise levitajateks rannikuelanike hulgas. Kohalikud meditsiinitöötajad ei olnud sel ajal aga just kõrgel tasemel - arstidest ja väljaõppinud velskritest oli puudus. Siberi kohalike Põhja Komiteede nõupidamistel arutati pidevalt arsti- ja veteri- 
naarabi olukord põhjarajoonides. Näiteks 1927. aasta pleenumil tuuakse välja, et suurel territooriumil Arhangelskist Koola poolsaarel kuni Tšukotkani leidub vaid 23 arsti- ja 45 velskripunkti. Selle hiiglasliku territooriumi haiglates oli kokku ainult 65 statsionaarset voodikohta. Pleenumil arvati, et arstiabi tõhustamine oleks heaks trumbiks võitluses šamanismi vastu. Samas olid aga velskrid väga viletsate oskustega. J. Niggol kirjutab:

Näiteks nägin ma üht lõbusat halastajaõde, kes tunnustas, teadis ja "leidis" ainult kahte haigust ja nende nimetusi - bronhiiti ja pleuriiti. Kõigi nende ja muude haiguste vastu teadis vaid ühtainust arstimit riitsinusõli.

Kõigi põhjamaade ainsa arstipunkti ametlik juht, velsker, ravis gonorrhead suu kaudu põrgukivipillidega ja pidas nähtavasti kaunis palju lugu sagedaste silmahaiguste, conjunctivitis'e ja trachoma, raviviisist pärismaalaste kombe järgi, lastes silmi hõorruda penis'e otsaga. Sel silmade arstimisviisil on põhjamail, kus ei tunta seepi ega sõrmede puhtust, põhjendatud alus, sest on ju penis'e ots puhtam kui kasimatu sõrm ja vesi koerte poolt puhtaks lakutud anumas (Niggol 1937: 69).

Nõukogude võimu kehtestamisel olukord esialgu ei muutunud. T. Sjomuškin kirjutab:

Siin Tšukotkal ei olnud kahekümne neljandal aastal mitte ühtegi arsti ega ühtki velskrit. Miilitsaülem oli käed ära külmetanud. Sõitis faktooriasse, vaevalt sai end soojendada, ja natukese aja pärast hakkasid tal käed mustendama. Ühel käel läksid sõrmed, teisel terve kämmal.

Inimesed ikkagi said aru, et surmast ei pääse, kui õigel ajal ei võeta kätt otsast maha. Otsustati teha operatsioon kodusel viisil. Selle töö võttis ette faktooria juhataja. Alguses otsustati miilitsaülem piiritusega täis joota, siis aga leiti koduapteegis juhuslikult narkootilisi aineid. Pandi magama. Võeti kõige tavalisem saag, kuumutati seda piirituseleegil, ómbluste jaoks leotati piirituses põdrasooni ja faktooria juhataja koos raamatupidajaga saagisid heast südamest käe otsast maha. Kui hakati lõikama teise käe sõrmi, ärkas miilitsaülem unest ja pistis kisendama. Nemad talle veel unerohtu [---] Pärast ei tahtnud ülesse ärgata (Sjomuškin 1953: 23-24).

Arvestades eeltoodut, ei olnud midagi imestada, kui kohalikud elanikud pöördusid abi saamiseks šamaanide poole. Väga paljudel juhtudel nad saidki sealt abi. Katkend J. Niggolilt: 
Ristiusku täidavad nad paganausu õpetuse ja kommete järele, haiguste ja hädade puhul pöörduvad šamaanide poole ja ohverdavad vihaste vaimude leevendamiseks oma paremaid koeri. Penšina lahe ääres korjakkide külades näed sageli elamu külge kinnitatud üht või mitut latti, mille otsa on torgatud ohvriks tapetud koera pea (Niggol 1937: 27).

Kuuskümmend aastat hiljem külastasime mitmel korral Markovot. See oli tüüpiline täielikult venestunud põhjapiirkonna asula, kus oli väga palju endisi vange ja nende järeltulijaid. Et alkoholi oli poest vabalt saada (Markovot ei loetud rahvuskülaks ja seal ei kehtinud kuiv seadus), oli enamik külaelanikke purjus. Koerapäid teivaste otsas me ei märganud. Ise elasime Markovost 300 kilomeetrit põhja pool Maeni jõe ääres Vaegi asulas. Seal oli küll näha ohverdatud põhjapõtrade sarvi siin-seal rippumas.

Tšuktšid süüdistavad kõikide haiguste tekkes pahasid vaime (kele, ketlja). Vaimud, kes on nakatatud haigustega, nagu katk, gripp, leetrid (tapjad ketljad), on nii hirmsad, et isegi šamaanid on nende vastu jõuetud. V. BogorasTan vestles šamaaniga, kelle nimi oli Kriiskav Naine ja kes ütles talle, et selliste vaimude vastu on mõttetu isegi loitsimist alustada. Nad võivad vihastada ka sinu peale ja sulle endale kallale tungida.

1884. aasta katku ajal püüdsid paljud inimesed katku ohverdamistega peatada. Nad tõid vaimudele ohvrianniks sooja veresuppi ja rasva, valasid ohvriannid väikestesse ümmargustesse nahkkaussidesse ja asetasid jarangade läänekülje äärde lumele, sest sealt ilmakaarest tulid pahad vaimud. Ketljasid ei rahuldanud need ohvriannid ja epideemia ei lõppenud. Ei aidanud ka kõige südamelähedasemate asjade - püssi, parima koera- või põdrarakendi - ohverdamine (Bogoraz-Tan 1939: 38), vaid katk möllas edasi. Ainsana aitas katku vastu kiire põgenemine ja põhjapõdrakasvatajad liikusid koos karjaga kaugele itta, lootes, et pahad vaimud, saades teada, et vahepeal on tühi maa, külm tundra, kus pole süüa, pööravad teise suunda ega tule neile järele.

1887. aastal jättis šamaan Amce maha haigestunud väimehe ja pereliikmed ning põgenes koos karjaga idapoolsele karjamaale. Mõne aja pärast pöördus ta tagasi. Püüdes mitte paljaste kätega puudutada väimehe jarangat, tegi ta avause elamu külgseina, läks sisetelgi juurde ja leidis sealt surnud väimehe. Ta ei hakanud teda maha matma, vaid ütles: "Oo, sa oled tõepoolest surnud. Mis ma saaksin sinu heaks teha? Sind ei ole mõtet viia tundrasse. Siin on sul terve jaranga. Hea, et ma sind vähemalt nägin. Hüvasti. Ma lähen ära." Ta jättis kõik sinnapaika ja lahkus.

Paljud karjused, püssid käes, keelasid katku eest põgenevatel sugulastel oma jarangadele läheneda, ähvardades neid ise surmata, kui nad ei lahku. 
V. Bogoraz-Tanile jutustas tšuktš nimega Peplu, kuidas ta 15 -aastase poisikesena jäi ainsana oma perest ellu. Ta lahkus surnud pere juurest ja tahtis minna elama onu juurde, kes, püss käes, ohutus kauguses poissi ähvardas, üteldes: "Sa kuulud ketljale. Mine tagasi teiste juurde ja tapa ennast noaga või poo üles. Siia ära oma nägu enam näita.” Poiss oli sunnitud minema tagasi oma sugulaste juurde.

Tšuktši šamaan, nii nagu ka teiste rahvaste šamaanid, pole, vaatamata sellele, et ta ravis abivajajaid, suuteline ennast ravima (Bogoraz-Tan 1939: 139).

Tšuktši šamaanid kasutavad maagilises meditsiinis mitmeid meetodeid. Üheks levinumaks on hinge (uvirit) tagasitoomine. Selle meetodi põhjendus on, et pahad vaimud võtavad osa hingest kaasa, mis tuleb üles leida - siis saab inimene terveks. Abivahendiks haige hinge leidmisel võib olla eriline müts, mille šamaanid panevad oma patsiendile pähe. V. Bogoraz-Tan kirjeldab üht sellist pööratud nahast, narmaste ja kahe vasakule küljele kinnitatud $80 \mathrm{~cm}$ pikkuse põimitud patsiga peakatet. Lühikene kippuriga pats oli kukla taga. Sellist mütsi kasutati ka peavalude raviks, aga sel juhul oli mütsi pealael lõhik (Bogoraz-Tan 1939: 138).

Rituaal hinge tagasitoomiseks algab bubini põristamise ja lauluga. Seejärel kukub šamaan maha ja on varjusurmataolises seisundis. V. BogorazTan lisab, et viimasel ajal asendatakse see seisund tavalise unega. Kui kadunud hing on leitud, šamaan ärkab, hing sumiseb putuka kombel ja lendab ümber haige. Šamaan püüab hinge läbi rinna, silma või pealae kehasse tagasi viia. Hinged, nagu ka pahad vaimud, tekitavad lennates suminat. Tihti šamaan küsib patsiendilt: "Kas sa kuuled suminat? See on sinu hing, mis lendab ümber meie." Minuti pärast ta küsib: "Kas kuuled kära? Seda häält teevad bubini nahal sinu hinge väikesed jalakesed." Tugev šamaan võib anda haigele osa oma hingest. Seda sel juhul, kui ta ei leia kadunud hinge üles. Sellisel juhul sai patsiendist šamaani poeg (Bogoraz-Tan 1939: 140).

Teise meetodina kasutasid tšuktši šamaanid maagilist kirurgiat. Selle meetodi juures teeb šamaan näo, et avab haige koha, eemaldab mäda ja halva vere või vahel isegi terve haige organi. Šamaan lähendab oma näo patsiendi kehale, puhub selle peale või imeb mõnda aega haiget kohta. Arvatakse, et hing, kes abistab šamaani, on võimeline ravima või ära sööma haiguse tekitaja. Hõõrumine ja imemine on massaažitaolised toimingud ja neid kasutatakse eriti paisete, haavade ja äralöödud kohtade ravil. Šamaanid näitavad tihti putukaid või ogasid, mis on välja võetud haigete kehadest (Bogoraz-Tan 1939: 140).

T. Sjomuškin kuulis tšuktšidelt: 
Kele võib olla kivi sees, mille peale kütt tahab istuda, mütsi sees või ootamatult ilmuda nirgi kujul, hundi kujul. Kele võib asuda sõrme, silmadesse, kõhtu, hambasse. Haigusi omaette ei ole olemas. Kuri vaim valib välja inimese ja asub temasse. Inimene on haige, piinleb ja sureb.

Et alles hoida head vahekorda kelega ja teda mitte vihastada, tuleb tuua talle ohvreid.

Šamaanid on inimesed uskuma pannud, et kaitsevad inimesi kurjade vaimude eest. Usk vaimudesse osutus nii tugevaks, et selle kõigutamisele juhusliku agitatsiooniga ei võinud mõeldagi. Oli vaja kestvat, süstemaatilist tööd.

Sellepärast ilmusid tšuktšide lapsed kool-internaati šamaanimärkidega nägudel. Enne laste ärasõitu rannikule mürtsusid lumetormi ulgumise saatel šamaanide trummid, kostsid lasumislaulud šamaanid olid vaimudega ühendusse astunud. Ühe sõnaga, oli tarvitusele võetud kõik abinõud, et koolis kurjad vaimud lapsi ei tülitaks (Sjomuškin 1953: 34-35).

Ega meiegi esivanemate kujutelmad erinenud suurt tšuktšide omadest. Oskar Loorits kirjutab:

Algselt kujuteldi haigust ja surma võõrjõudude tungimisena inimesse, kusjuures haiguse ja surma vahel polnud põhimõttelist laadi vahet, vaid ainult jõukvantumi vahe: kui inimese jõud on tugevam kallaletungivast võõrjõust, siis ta saab sellest vabaks ja terveks, kui aga võõrjõud on tugevam, siis see vallutab ja suretab inimese. Kes on need kallaletungivad võõrjõud? - Tavaliselt need on selgesti teada: vaenlase relv või karu käpp veristab keha, nii et inimene sureb kohe või põeb mõnd aega jõukaotust, enne kui vabaneb võõrjõu hävitavast mõjust; vesi uputab, haigestab, aga ka puhastab, arstib (s.t annab lisajõudu), pikne lööb maha, uss nõelab jne. Just niisama võivad haigestada ja suretada teised inimesed ja eriti veel surnute hinged. Kehast või laibast irdunud hinged tahavad suurendada oma jõudu ja pü̈̈avad hankida seda teistelt.

Rõhutatagu, et seda ei ohjelda algselt mingid eetilised "hea" ja "kurja" mõõdupuud ega hinnangud. Surnute hinged tahavad nii öelda uuesti sündida ja siirduvad teistesse kehadesse nagu lastesse, putukatesse jne, kuid ka täiskasvanutesse pahatihti (Loorits 1990: 60).

Tõelistel šamaanidel on hüpnootilised võimed. Teisiti on raske seletada järgnevat: 


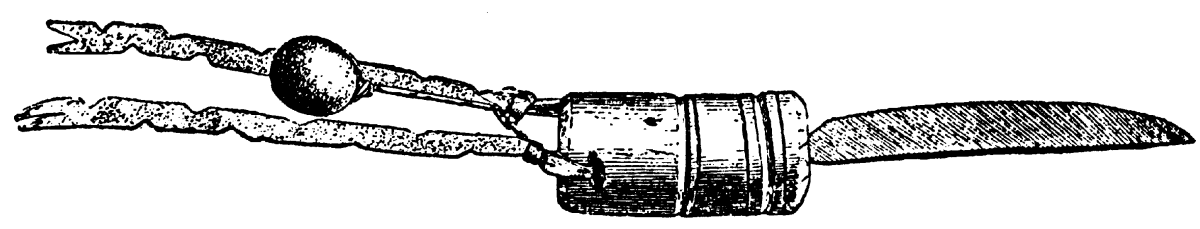

Joonis 4. Nuga (Bogoraz-Tan 1939).

Uurides patsientide haigeid siseorganeid, ta justkui võtab nad ükshaaval, kas tervetena või tükkidena, organismist välja ja paneb sinna tagasi. Selline operatsioon saab toimuda ainult spetsiaalse noa abil, millele on antud loitsude abil maagiline toime. Enne operatsiooni tuleb nuga igasuguste šamaanirituaalidega "soojendada". Kui rituaal on läbi viimata, võib selline nuga isegi tappa (Bogoraz-Tan 1939: 141).

V. Bogoras-Tanil õnnestus näha šamaan Kriiskava Naise rituaalinuga. See oli tavaline raudteraga nuga, millele oli tehtud lihtne puust käepide. Noa käepidemes oli kaks ümmargust avaust - sisselõiget -, mille külge oli kinnitatud kaks nahast lõigatud ripatsit. Käepideme külge oli seotud ka kanamunasuurune sinisest klaasist pärl. See klaasmuna oli väga vana ja Kriiskav Naine ütles, et selle andis talle tema vanaisa, kes ise sai selle otse "vaimult". Noatera oli kaetud roosteplekkidega, mis olid tekkinud pärast operatsioone patsientide verega määrdumise tagajärjel.

Raviriituste läbiviimist peab abistama luust lauake. See olevat Linnutee kingitus. Lauakese külge on kinnitatud kolm nahkfiguuri. Esimene neist on "pimeduse hing". Sellel kujul on käed pikemad kui jalad. Teine kuju on ühe käe, ühe jala ja üksteise taga asuvate silmadega. Selle "hinge" nimi on Inmetun. Kolmas kujutis on "nõidus", mille saatis talle üks vihavaenlane. Kuid šamaanil õnnestus see "nõidus" tee peal kinni püüda ja endale allutada nüüd täidab "nõidus" tema käske.

Kriiskav Naine rääkis, et nende instrumentide abil on ta läbi viinud mitmeid siseorganite operatsioone, kuigi tema naabrid ütlesid, et see šamaan on nii paljude operatsioonide sooritada jõudmiseks liiga noor (Bogoraz-Tan 1939: 142).

Toon ära ühe raviseansi kirjelduse, mis toimus viiskümmend aastat pärast V. Bogoraz-Tani Tšuktšimaa külastamist. See oleks nagu segu kahest esimesest kirjeldatud ravimeetodist.

Ühel õhtul jõime Vaegis tüdrukute toodud šampust ja küsisin, kas Niina on ka ise šamaani juures ravil käinud. Kooliõpetaja jutustas: 
"Kui olin laps, tekkis mul mingisugune põletik. Kael läks mõlemalt poolt kõrva tagant paiste. Mõlemal pool kõrva taga olid kanamunasuurused mügerikud. Ema viis mind šamaani juurde. Sel ajal elasime jarangades siin lähedal. Šamaaniks oli siis üks tšuktši meesterahvas. Ta sai nõukogude võimu kehtestamisel paar aastat hiljem surma.

Mind pandi jarangas põdranahkadele pikali. Šamaan ajas emaga juttu. Nad olid eemal ja ma hästi ei kuulnud, mida nad omavahel rääkisid. Siis istus ema teiste naistega jaranga seina äärde nahkadele. Šamaan istus minu vastu teisele poole lõket. Ta põristas aeg-ajalt bubinit, siis näris midagi ja jõi teed peale. Tema abiline pani mulle ka midagi kibedat suhu ja käskis teed peale juua. Kui šamaan oli juba tükk aega bubinil mänginud, hakkas ta korraga kriiskama. Ta kargas püsti ja hakkas ümber lõkke tantsima. Minul kadus teadvus nagu ära ning ma ise ei näinud midagi.

Ema jutustas pärast, et šamaan oli võtnud hingedega ühendust ja pärast seda maha kukkunud. Abiline oli tema kõrvale läinud ja kuulanud, mida šamaan räägib. Kui šamaan toibus, siis ohverdati ketljale noor põdravasikas. Mul määriti nägu ja haige kael põdravasika verega kokku. Šamaan oli jälle ümber minu tantsinud ja siis tõmmanud mul mõlemalt poolt kõrva tagant välja kaks karuküünt meenutavat kõverat kivi, mis olevat olnud minu haiguse põhjuseks. Kui ma üles ärkasin, oli kael hirmus valus, aga paar päeva hiljem olin täiesti terve. Mügerikud kõrvade tagant olid kadunud. Nende asemel oli pehmed nahavoldid (vt Siimets 1999b).

Kirjeldatud loos oli tegemist maagilise kirurgiaga. Seega, vaatamata ebausuks tituleerimisele, valdasid šamaanid vanemaid haiguste kõrvaldamise võtteid.

Kolmandaks meetodiks ehk maagilise meditsiini vormiks oli patsiendi välise kuju muutmine, et pahad vaimud teda ära ei tunneks. Mehed hakkavad sel juhul kandma naiste riideid. Sel eesmärgil muudetakse ka soengut. Välimuse muutmist kasutavad näiteks ka mõrtsukad, kes oma kuritööpaigast lahkumiseks kasutavad vastassugupoole rõivaid, sest tapetu hing võib mõrvakohta ketljana tulla tagasi. Tagasitulnud vaim on ketlja-kättemaksja, kes vallutab kurjategija keha ja sunnib teda tegema terve rea halbu tegusid, et naabrid karistaksid teda tema halbade tegude eest.

Lõpuks kirjeldan üht raviseanssi, mille viis läbi minu brigaadi šamaan Ejgeli.

Oli septembri lõpp, minu märkmete järgi 23. september. Jõudsime õhtul hilja tagasi jarangade juurde. Kari jäi mõned kilomeetrid jarangadest eemale, karjavalvesse jäid Veem ja Nuwat.

Ejgeli läks elama oma jarangasse. Minule anti magamiseks polog brigadiri Remkölömi, keda kutsuti tavaliselt vene nimega Ivan Ivanovitšiks, jarangasse. 
Perenaine keetis põdraliha, pakkus teed, mille kõrvale oli väikesele, umbes 20 sentimeetri kõrgusele lauale taldrikuga ka tükisuhkur. See oli tore, sest ma ei olnud magusat juba paar kuud üldse saanud. Kõhu täis söönud, pugesin pologisse ja kavatsesin magama jääda.

Polog asus jaranga sissekäigu juurest lõkke suunas vaadates lõkkest vasakul. Vedelesin oma pologis põhjapõdranahkadel, kuid und ei tulnud ja teha ei olnud midagi. Õues oli juba öö. Ega tegelikult sellepärast veel väga pime ei olnud, sest õues paistis täiskuu. Korraga tuli Ejgeli meie jarangasse ja palus mu oma jarangasse. Tal olevat noorte ja tugevate meeste abi vaja. Läksingi. Seal olid juba meie brigaadi mehed koos mõningate võõraste noormeestega ees. Keset jarangat põles rahulikult lõke. Pean ütlema, et kõikide rituaalsete toimingute juures, millistest mul õnnestus osa võtta ja mida viis läbi šamaan, põles alati lõke. Kindlasti toimusid paljud rituaalid, nagu kirjeldavad V. Bogoraz-Tan ja teised teadlased, täielikus pimeduses, aga mul neist osa võtta ei õnnestunud.

Kõikide rahvaste juures on tuli olnud püha ja paljude rahvaste juures on ta seda tänapäevani. Tule kaudu saadeti ohvriande jumalatele või vaimudele. Tule abil vabanes hing vaimsest kehast. Tule abil saadi lahti kurjast. Viibides 2005. aastal Anapurna mägimatkal Nepaalis, külastasime erinevate usundite templeid, nägime põletusmatuseid ja viibisime 3800 meetri kõrgusel asuvas pühas kultusekohas Muktinathis. Juba üle kolme tuhande aasta tagasi hakkasid seda kohta külastama palverändurid. Seal asub üks vanimaid ja tähtsamaid hinduismi ning budismi pühamuid - Igavese Tule Tempel. Selle koha müstiline tähendus on saanud alguse sinkjalt maagaasileegilt, mis kaljuallika vee kohal tantsib ja altarile võbisevat valgust annab. Kohapeal asuvad veel mitmed templid ja budistide klooster.

Augustis kogunevad palverändurid pühasse kohta, kus toimub iga-aastane suur pidustus janaipurnima. Hinduistidel on Igavese Tule Templi territooriumil oma tempel, kus toimub sel päeval pühade nööride vahetus ja 108 pronksist püha lehma pea kujulisest veesülgurist väljapurskava vee all enda väline puhastamine-pesemine.

V. Bogoraz-Tan kirjutab, et tšuktšide uskumuste kohaselt on tulekolle vaimude jarangasse sisenemise kohaks. Ketljade sisenemise tõkestamiseks laotakse ümber lõkke kivid. Ka korjakkidel sisenevad lõkkeaseme kaudu jarangasse halvad vaimud - kamakid. Korjaki muinasjuttudes muutuvad koldekivid pahade vaimude sisenemisel kaljudeks, mis eraldavad kolde jarangast ega lase kamakke läbi. Endale vajalikke vaime kutsub šamaan jarangasse loitsudega (Bogoraz-Tan 1939: 125). 
Raamatus Mütoloogiaid kogu maailmast võime lugeda Maggie Boltoni, Ameerika Põlisrahvaste Uuringute Keskuse esindaja näidet tule pühadusest slaavlaste juures. Ta kirjutab:

Sügavate šamanistlike uskumustega slaavi agraarrahvad suhtusid tulesse nii suure aukartusega, et vanemad keelasid lastel tule sü̈tamise juures isegi kõva häält teha, karjuda või vanduda. "Tulekoerad" - metallist tugipuud, mis toetasid halge lõkkes - pärinevad tule šamanistlikust seostamisest vaimude ja jumalatega.

Tuli on slaavlastel alati püha olnud. Tuli oli jumalik kingitus, mille taevajumal Svarog heitis maale välgunooltena (McKenzie \& Prime \& George \& Dunning 2002: 80-81).

Tšuktši šamaanide poolt riituse ajal jarangasse kutsutud vaimud võivad siseneda ruumi ainult šamaani keha kaudu. Sellisel juhul hakkab šamaan tegema tundmatuid, ebaselgeid hääli või kriiskama. Pidupäevadega seotud riituseseanssidel hämmastab šamaan pealtnägijaid erinevate lindude ja loomade häältega, kes raevukalt kopsivad jalgadega vastu maad ja hüppavad ringi, purustades kõik ettejäävad asjad. Šamaan, kelle kehasse on tunginud ketlja, kaotab võimaluse inimestega kõnekeeles suhelda ja võib väljendada oma tundeid ning soove ainult seosetute lausetega või žestikuleerides. Kui vaim tuleb või lahkub šamaani kehast, teeb šamaan vastava looma häält. Ta roomab neljakäpakil, häälitseb või krigistab hambaid (Bogoraz-Tan 1939: 125).

Aga jätkame minu kogetud raviriitusega.

Lõkke kõrval põhjapõdranahkadel lamas umbes neljateistkümneaastane poiss, kelle nimi oli Ajwan, seljas kufljanka, mis oli peaaegu vööni üles keritud. Pükse tal jalas ei olnud. Tema parem jalg oli alates jalalabast kuni poole reieni sinine ja kohutavalt paistes. Eriti kole oli parema põlve ümbrus. Vasak jalg oli poole peenem. Poisi nägu oli vaevatud ja valulik. Inimesed istusid põhjapõdranahkadel ümber lõkke, jäädes näoga lõkke taga asuva pologi poole. Ajwan oli koos sõbraga mägedes lumelambaid jälitades ettevaatamatult lahtisele kivile astunud. Kivi oli jala alt liikuma läinud ja noormees oli koos kiviga järsakust alla veerenud. Teine lahtipääsenud kivi oli mäest alla veeredes poisi jalga vigastanud. Õnneks oli temaga kaasas sõber, 16aastane Rultuge, kes oli võtnud tema asjad enda selga. Rultuge käis Magadani Põllumajandusinstituudis ja oli õppinud mingil määral ka esmaabi, mistõttu ta oli Ajwani jalga vaadates kahtlustanud luumurdu. Ta oli võtnud kaks lepatoigast, tõmmanud oma puuvillase särgi ribadeks ja lahastanud Ajwani jala. Komberdades olid nad mägedest jarangade suunas liikuma hakanud ja 
paari päevaga lõpuks nendeni jõudnud. Kuna oli teada, et Ejgeli jõuab lähiajal jarangade juurde noore põdra pidustusi läbi viima, ei hakatud 500-600 kilomeetri kauguselt Anadõrist ega veel kaugemast Markovost helikopterit tellima ja nüüd lamas Ajwan šamaani telgis.

Ejgeli oli varjunud pologi. Istusin meeste kõrvale põdranahkadele. Vaatasin lõkke rahulikku põlemist. Siis hakkas pologist kostma tasaseid ja aeglasi trummilööke ning kellukeste helinat. See müdin hakkas paisuma ja kuulda oli erinevaid hääli. Miski sahises. Tundus, et keegi sisenes pologi. Siis kostis, et pologis niutsub kutsikas, samas oli kuulda jälle lindude sädinat. Bubini tümin paisus ja pologist väljus selg ees kufljankasse riietunud Ejgeli. Tal oli peas müts, mille tipus olevate nurkade külge olid õmmeldud kippurid. Ta pööras ennast näoga meie poole. Nägin, et tal olid kellukesed kõrvas. Vasakus käes oli Ejgelil ümmargune trumm, mille küljes rippusid erinevad kellukesed ja luust rõngad. See oli hoopis suurem ja kellukestega trumm, mitte see, mille ta koos minuga karja minnes kaasa võttis. Sellist oleks olnud suuruse tõttu ebamugavam tassida. Vähimagi liigutuse juures tegi trumm väga mitmesugust häält, kõige kõrgemast kõige madalamani. Kellukesed helisesid, luurõngad kobisesid. Aeg-ajalt lõi Ejgeli kuivatatud, nahaga kaetud põhjapõdravasika sääreluuga, mille otsas oli sõrg, vastu bubinit. Ka selle rütm vaheldus - vahel lõi ta trummi aeglaselt, vahel kiirelt.

Aeglaselt, samm sammu järel lähenes ta lõkkele, ise vahetpidamata bubinit põristades. Kord lõi ta vastu trummi kiiresti, kord aeglaselt, kord tugevalt, kord nõrgalt. Ise ta laulis oma tavalist täishäälikutest koosnevat laulu: Ii-iii-iii-iiii, oo-ooo-oooo-ooooo-a-aа-aаa, аaаa, ии-иuи, еe-еeеe-еeеe. Hääl tõusis ja vajus. Mehed tõusid püsti. Ka mina tõusin püsti. Šamaan ees, läksime jarangast välja. Haige jäi lõke äärde pikali.

Jaranga ette olid naised süüdanud väikese lõkke. Lõkke taga oli narta külge seotud põhjapõdravasikas.

Ejgeli põristas trummi ja laulis: Ii-iii-iii-iiii, a-aa-aaa, aaaa, oo-ooo-ooooооооо, ии-иии, ее-еее-ееее-ееееее. Ta tantsis ümber tule. Aeg-ajalt hüppas ta õhku ja kriiskas tugeval häälel. Mõnda aega nõnda tantsinud, jäi ta vasika juurde seisma ja uuris teda pingsalt. Siis ta asetas oma bubini nartale. Remkölöm lähenes talle tšaadi ja tupes odaga, odakelluke kõlises, kui mees oda šamaanile ulatas. Ejgeli vabastas oda tupest. Ornamentidega kaunistatud haljas odatera välkus lõkkevalgel.

Remkölöm pani tšaadi vasikale kaela ja tõmbas pingule. Vasikas hakkas meeleheitlikult hüppama. Mõne aja pärast rabelemine vaibus. Loom punnis tšaadi tõmbele vastu. Nii oli tema keha raskuspunkt tahapoole kallutatud ja esijalad ette poole välja sirutatud, jättes vasaku külje südame poolt vabaks. Ejgeli tegi ühe kiire torke odaga. Vasikas hakkas jälle metsikult tšaadi otsas 
hüplema, aga varsti kukkus ta maha, vasak külg ülespoole. Haavast purskas iga südamelöögiga verd. Ejgeli võttis haavast veel elusa looma verd ja tõmbas kõikidele meestele näo peale kolm verist jutti - otsaette ja mõlema põsesarna peale. Nina peale tõmmatud veremärk algas lauba keskelt ja lõppes kahe silma vahel. Põskedele tõmmatud jutid algasid silma alt nina lähedalt ja lõppesid põsel. Siis andis ta meestele korralduse ja mõne minutiga oli vasikal nahk maas, põdrapea koos rinnaesise naharibaga ulatati Ejgelile, kes asetas selle narta peale, nii et looma pea jäi vaatama lääne suunas. Veri kõhuõõnsusest tõsteti malmpotti. Liha pandi teise potti, kus oli juba vesi, ja pott asetati koos lihaga tulele. Enne jarangasse sisenemist võttis Ejgeli potist parema kamaluga verd ja viskas seda igas suunas. Samuti pritsis ta verd jaranga sissekäigu ette maha ja viskas lõkkesse. Ka võttis ta väikesi lihatükikesi ja viskas neid laiali igas suunas ning lõkkesse. Väike luukauss põdravere ja lihatükkidega asetati põdrapea ette samblale. Siis võttis Ejgeli oma trummi ja sellele aeglaselt koputades sisenes jarangasse. Remkölöm sisenes tema järel, verega malmpada käe otsas. Ka meie läksime jarangasse. Remkölöm asetas põdraverepaja lõkke kõrvale.

Ejgeli põristas jälle bubinit ja hakkas laulma. Laul oli muutunud. Nüüd olid tema täishäälikute hulka siginenud ka üksikud kaashäälikud. Algas laul tavaliselt: Iii, aaa, ooo. Siis kõlasid: Aa-ah, aaa-jah, kaaa-ah, aaa-ah, kaa$a h$.

Seejärel asetas Ejgeli trummi lõkke kõrvale, tõmbas verega haige näo peale samasugused triibud kui meile ning määris ta jala alt kuni poole reieni verega kokku. Seda teinud, võttis ta trummi, põristas sellel mõnda aega, laulis lühidalt rea täishäälikuid ja istus maha seljaga pologi ning näoga lõkke poole.

Kuna tšuktšid keedavad liha umbes 5-10 minutit, käis Vatap jarangast ära ja tuli tagasi lihakatlaga, mille ta asetas lõkke ette. Pärast kesköist einet istuti uuesti oma kohtadele. Ka Ejgeli jäi istuma oma kohale.

Ta alustas oma laulu: Ii-iii-iii-iiii, oo-ooo-oooo-oooo-a-aa-aaa, aаaa, uиuиu, eе-еeеe-еeee. Hääl tõusis ja vajus. Edasi läks laul üle lühikesteks silpideks: Aaa-ah, aaa-jah, kaa-ah, aaa-ah, kaa-ah.

Meeste hulgast hõigati viimastele silpidele sekka: $H u k$, $h u k$. Ejgeli jäi vait ja vaatas üles jaranga suitsu suunas. Ta jälgis tähelepanelikult ülal toimuvat ja sulges silmad. Vaikus kestis mõni minut. Seejärel laskis šamaan oma pea longu ja tardus. Hetke pärast hakkasid tal hooti vabisema õlad, seejärel lõi vabisema pea ning varsti õotsus terve ta keha kramplikes tõmmetes.

Lõkketuli läks ootamatult suureks ja hakkas tekitama musta suitsu. Ma ei näinud, et keegi oleks midagi lõkkesse visanud. Võib-olla olin liialt ametis Ejgeli jälgimisega. 
Šamanismist ja tšuktši šamaanide ravimisriitustest

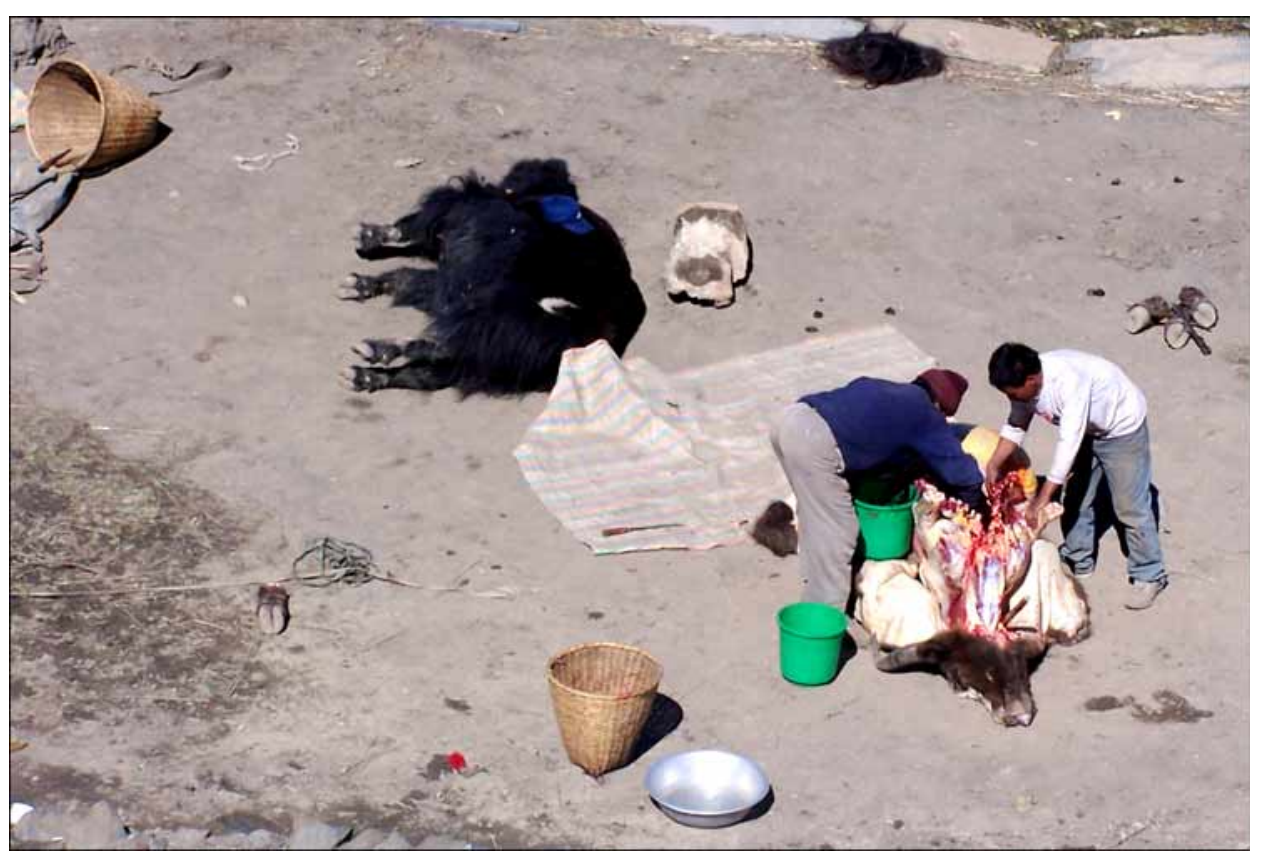

Foto 1. Jaki ohverdamine valguse pühal. Nepaal 2005. Foto Hans Linask.

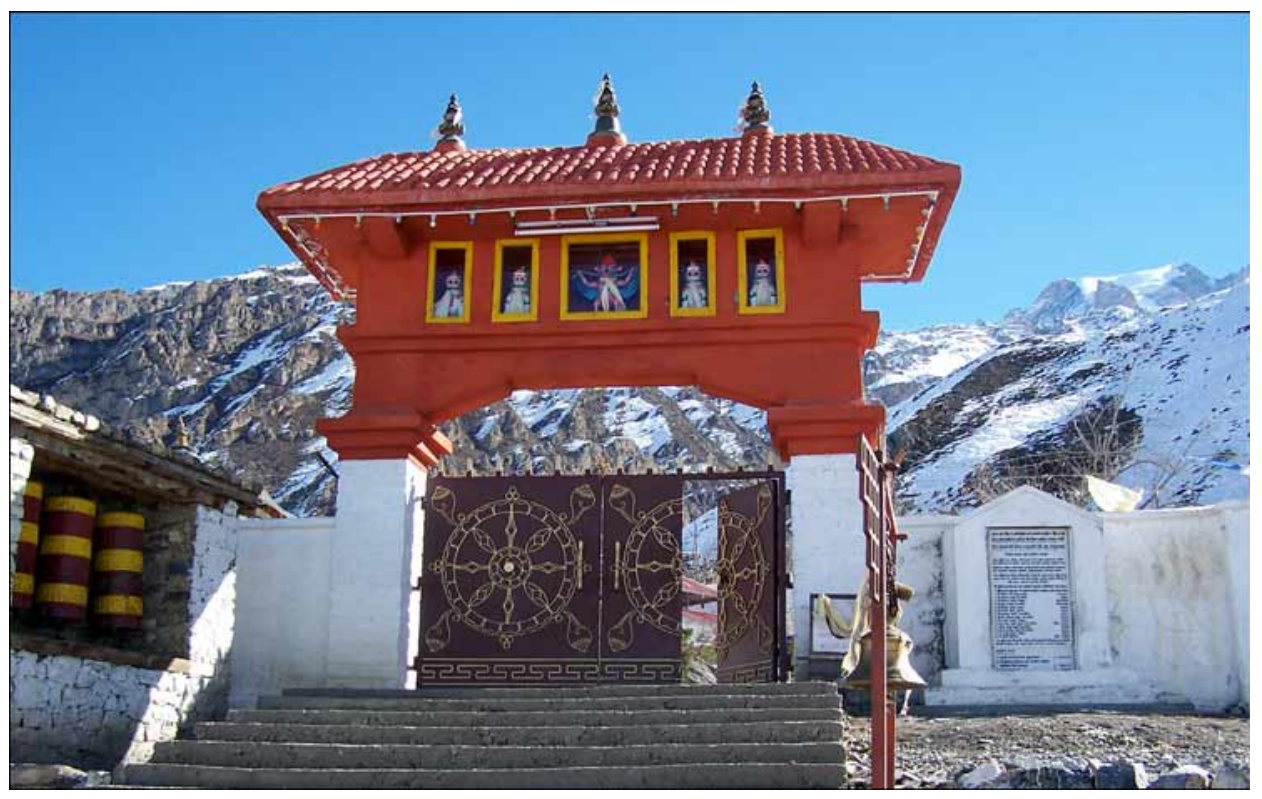

Foto 2. Igavese tule templi peavärav. Nepaal 2005. Foto Ivar Järving. 
Ejgeli kummardus põlvili poisi kohale ja võttis Ajwani kuhfljankast oma kätega kinni. Ta pea hakkas uuesti värisema ning põlved kergelt vabisema. Lastes poisi käte vahelt lahti, haaras Eigeli trummi ning raputas seda kõigest jõust oma pea kohal. Kellukesed helisesid, luurõngad plõgisesid. Trummi vastu rinda surudes tõmbus šamaan krampliku liigutusega kössi, justkui oleks tal kange kõhuvalu. Ta otsaette tekkis higi. Järsult end sirutades lõi ta vasika jalaluuga vastu trummi ja hakkas loitsima: Ii-iii-iii-iiii, oo-oooоооо-ооооо-а-аa-аaа, аааа, ии-иии, ее-ееее-ееее...

Pikad silbid vaheldusid lühikestega. Aeg-ajalt oli kuulda järske karjeid ja kriiskeid ja vahel ta pobises mingeid silpe. Minu tšuktši keele oskus ei ole just kõige parem, aga mu kõrvad püüdsid pobinast kinni üksikuid tuttavaid sõnu ja lausekatkendeid. Šamaan tutvustas vaimudele, kelledest üks oli Kirvir, ennast, kohalolevaid karjuseid ja laagriinimesi. Arvasin kuulvat näiteks lauseid ja sõnu: Gõmnan enmen ligi, ginin nõnnõ Kirvir 'Ma juba tean, et su nimi on Kirvir', Gõmnin nõnno Ejgeli 'Minu nimi on Ejgeli'. Nimetati Remkölömi, Vatapi, Jelo, Rultuge jt nimesid. Edasi liitusid riitusega vist loomade ja lindude vaimud. Oli kuulda vihinat ja klõbinat ning pominas võis eristada tuttavaid sõnu: Gõt goranõ 'Sina oled põder', Göt tširap 'Sina oled kotkas'. Märgiti ära vaimudele toodud annetus ja toidu valmistamine: Tjäkicgön uwirkönin 'naine keedab liha'.

Seejärel räägiti jahil käinud noorukitest, kes olid natukene üleannetud ja seetõttu sunnitud pärast öö mägedes veetma: Ajwan vage obitta anzkara görgol 'Ajwan oli terve öö kõrgel (üleval mägedes)', Ga pela tore lela jrõ 'Kaotasime silmist'. Pobinast oli arusaadavalt kuulda ka küsimus: Kailekõn minkri? 'Mis teha?'.

Liigutused muutusid üha järsemaks, karjed üha kõvemaks. Tekst ja pobin muutusid arusaamatuks. Tundus, et keegi vastas kusagilt kaugelt Ejgelile. Tšuktši keeles nimetatakse sellist tegevust Kalatkougön 'vaimudega suhtlemine'. Šamaan leiab omale vajalikud vaimud ja need vastavad talle.

Siis langes Ejgeli haige kõrvale selili ja hakkas väänlema nagu tõvehoos. Kellukesed ta kõrvade ja trummi küljes tilisesid. Suuäärtele ilmus valge vaht. Šamaan kattis oma näo trummiga, tardus ja lamas liikumatult. Ka Ajwan tema kõrval ega mehed jarangas ei liigutanud ennast. Valitses täielik vaikus. Musta suitsu ajanud lõke põles jälle tavaliselt, rahulikult.

Siis hakkas Ejgeli liigutama ja võttis trummi näo eest ära. Valge vaht ta huultelt oli kadunud. Tema ilme oli tõsine, kuigi mulle tundus, et natukene väsinud. Mees pani trummi kõrvale ja kummardus poisi jala kohale. Ta asetas ühe põdranahast istumispadja poisi jala alla, nii et see jäi natukene varvastega ülesse poole. Kätega poisi jalga mitte puudutades, hakkas ta tegema liigutusi ülevalt reiest alla kuni jalalabani. Šamaan hoidis käsi umbes kahe 
sentimeetri kaugusel jalast. Üks käsi oli ühel pool jalga ja teine täpselt samal kohal teisel pool jalga. Paralleelselt kätega liigutusi tehes oli ta ise vait. Ka jarangas olev seltskond istus vaikides. Aeg-ajalt lakkus Ejgeli oma keelega jala siseküljest haige põlve. Siis võttis ta bubini, põristas seda põlvili olles natukene aega ja laulis oma täishäälikutelaulu.

Kusagilt kaugemalt jaranga lae alt kostis hääli ja naginat. Seejärel pani ta trummi enda kõrvale ja hakkas uuesti tegema paralleelsete kätega liigutusi reiest jalalaba suunas. Mõne aja pärast lakkus ta keelega uuesti põlve sisekülge ja hakkas seal mingit kohta imema. Verine põlve sisekülg muutus verest puhtakslakutuna heledamaks. Imemiskohta hakkas tekkima tumedam plekk - "maasikas".

Nii kätega liigutades ja vahetevahel bubinit mängides kestis see raviseanss paar tundi. Seanss lõppes trummi põristamise ja lauluga. Ma tundsin ennast õudselt väsinuna, aga arvasin, et see on pikast tööpäevast. Ka teised jarangas haigutasid. Pologisse jõudes suikusin kohe unne. Hommikul ärgates ootas mind peale sööki põdrakarja minek.

Sel päeval ja ka järgmistel jaranga juures oldud päevadel olin ma karjas iga kord erinevate jarangas elavate meestega. Ju oli Ejgelil oma asjaajamisi. Esimesel päeval oli Ejgeli asemel Vatap, teisel Remkölöm, kolmandal jarangade juurest üks vanem mees Pnoi.

Järgmisel õhtul pärast karjast tulekut kogunesid mehed jälle Ejgeli jarangasse. Õue enam lõket ei tehtud, uut looma ei ohverdatud. Ajwani jalg nägi tunduvalt parem välja. Palavik ja põletik olid alanenud. Ainult põlv oli veel punane ja paistes. Ravimine algas jälle Ejgeli lauluga pologis. Söödi ohvrivasika verest tehtud veresuppi ja keedetud liha. Seejärel asus Ejgeli ravima. Täpselt samuti liigutas ta käsi paralleelselt reiest jalalabade suunas jalga kätega mitte puutudes, lakkus keelega haige jalga, imes kindlat kohta põlvel.

Nii kätega liigutades ja vahetevahel bubinit mängides kestis see raviseanss jälle paar tundi. Seanss lõppes trummi põristamise ja lauluga. Ja jälle tundsin ma ennast õudselt väsinuna.

Kolmandal päeval nägi Ajwani jalg juba peaaegu normaalne välja. Põletikuline, punane plekk põlvel oli vähenenud umbes 10 -sentimeetrise läbimõõduga ringjaks jäljeks, mille keskel oli tumelilla umbes sentimeetrine "maasikas". Selle keskele omakorda oli naha alla ilmunud kollane plekk (mädakolle). Seanss oli praktiliselt sama eelmisel päeval toiminuga.

Rohkem meid Ejgelile appi ei kutsutud. Nagu ta ise ütles, võttis kätega ravimine talt palju energiat ja meid oli kutsutud üritusel osalema, et ta saaks meie energiat ravimisel kasutada. Sellepärast me pärast raviseanssi kõik nii väsinud olimegi. 
Ejgeli kohta võib ütelda, et kindlasti olid tal peale ravitsejaomaduste ka selgeltnägemise võimed. Mehed tõid mulle ühe näite nende olemasolu kohta. Ejgeli oli ühel talvel meestega jarangade juures. Ta viis läbi järjekordset rituaali ja oli sellega tegevuses poole ööni. Pärast oli šamaan oma pologisse magama heitnud. Kuid vaevalt oli ta uinunud, kui teda äratas hirmus unenägu. Unes oli ta näinud, et põhjapõdrakarja ründasid hundid. Jarangades kõik magasid. Ejgeli riietus kähku, ajas ka teised karjused üles, käskis põdrad nartade ette rakendada ning võtta püssid ja kõik karjused sõitsid põdrakarja juurde. Õnneks ei ole kari talvel jarangadest kuigi kaugel. Šamaan oli unes näinud, kuidas hundid olid põhjapõdrakarjast hulga põtru maha murdnud. Mehe unenägu ei valetanud. Nad jõudsid sel öösel karja juurde natuke enne huntide tulekut. Väljas oli nagu ikka talvine polaaröö ja midagi ei olnud näha. Siis oli kari korraga erutunud ja ringiratast jooksma hakanud - nii kaitsevad suured loomad väiksemaid rünnaku eest. Paar põtra langes küll huntide kallaletungi ohvriks, aga ilma meesteta oleksid nad pool karja maha murdnud.

Selliseid ja muid unenägusid oli ka teisi. Minule kordas ta meie rännaku ajal mitmeid kordi, et püüa unenägusid meelde jätta. Eks ma ole oma elus ka püüdnud seda teha ja aeg-ajalt on sellest isegi kasu olnud.

Minu kogemuste põhjal on šamaanid erilised inimesed, kes juba sünnivad erilistena. Sellisel juhul on neil sündides mingi eriline märk, mille järgi nad

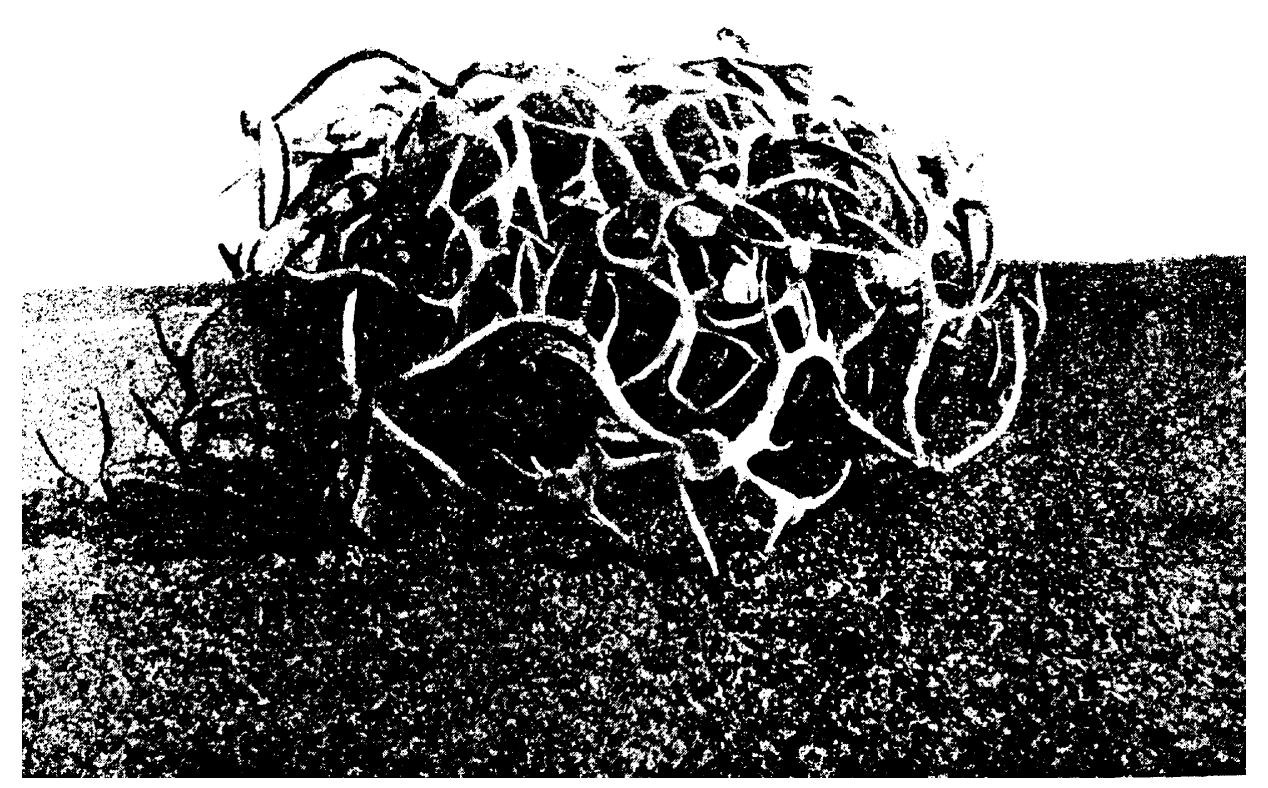

Joonis 5. Ohverdatud põhjapõtrade sarved (Bogoraz-Tan 1939). 
ära tuntakse. Kindlasti ei ole nad aga vaimuhaiged. Minu arvates on iseloomustanud šamaani olemust väga selgelt John Bowker:

Šamaanid hoiavad kontrolli all oma kehas olevaid vaime ning võivad lahkuda tavaeksistentsist, et rännata või lennata teistesse maailmadesse. Šamaan, kelleks tavaliselt on mees, võib võtta hallutsionogeenseid aineid rituaalide läbiviimiseks või teadvuse muutunud seisundite saavutamiseks. Nii siseneb šamaan vaimude ilma. Kurje vaime tuleb kontrolli all hoida või neid võita, headelt vaimudelt abi paluda. Inimeste maailma tagasi pöördudes on edukas šamaan midagi oma kogukonna jaoks teinud. Kui midagi viltu läheb, võib šamaan hulluks minna või isegi surra. Teistest maailmadest omandatud võimete ja teadmistega võib šamaan lauldes, masseerides või taimseid ja maagilisi vahendeid kasutades ravida, tulevikku ennustada, tüliküsimusi lahendada, loodusõnnetustega võidelda või vaenlasi rünnata (Bowker 2004: 200).

Šamanismi võib mingil määral õppida, aga kindlasti ei suuda selline inimene olla samaväärsel tasemel šamaaniga, kellel on juba sündides selleks eeldused ja kes omandab aastaid abilisena šamaani kõrval töötades tema kogemused. Vaatamata kõikidele šamaane halvustavatele juttudele teevad need inimesed oma tööd: ravivad, ennustavad, kaitsevad oma rahvast.

\section{Kirjandus}

Adamson, Andres 2002. Šamaaniks võib hea tahtmise korral õppida. Helios: Nii nagu ülevel nii ka all (http://helios.kolhoos.ee/discuss/msgReader $\$ 151$ - 12. juuni 2006).

Bogoraz-Tan 1939 = Богораз-Тан, Владимир. Чукчи II: Религия. Ленинград: Издательство главсевторпути.

Bowker, John 2004. Maailma usundid. Dorling Kindersley raamat. Tallinn: Varrak.

Haritonova, Valentina 2004. Religioossete-maagiliste tavade uurimise probleeme Venemaal 20. sajandi lõpus ja 21. sajandi alguses: Siber šamanismi ainetel. Mäetagused: Hüperajakiri 26, lk 105-123 (http://www.folklore.ee/Tagused/nr26/haritonova.pdf 12. oktoober 2006).

Horwitz, Jonathan 2002. Kogu elu on seotud ühte: Šamaani tee. Helios: Nii nagu ülevel nii ka all (http://helios.kolhoos.ee/stories/storyReader\$152 - 8. september 2006).

Johansen, Ulla 2000. Mida arvate šamaanidest? Postimees: Arter 18, 1. august (http:// arter.postimees.ee/leht/01/08/18e/lugu10.htm - 8. september).

Leete, Art 2000. Mida arvate šamaanidest? Postimees: Arter 18, 1. august (http:// arter.postimees.ee/leht/01/08/18e/lugu10.htm - 8. september). 
Lindrop, Aado 1996. Tubjaku Kosterkini loitsud. Mäetagused. Hüperajakiri 1-2, lk 30-43. http://www.folklore.ee/tagused/nr1/loits.htm - 3. september 2006).

Loorits, Oskar 1990. Eesti rahvausundi maailmavaade. Tallinn: Perioodika.

McKenzie, Michael \& Prime, Richard \& George, Lisa \& Danning, Ray 2002. Mütoloogiad kogu maailmast: Eri rahvaste mütoloogilised uskumused ja traditsioonid. Tallinn: Avita.

Niggol, Johhanes 1937. Matkapilte Kamtšatkast. Tartu: Noor Eesti.

Ojamaa, Triinu 1998. Šamaan kui loominimene. Kõiva, Mare (toim). Sator: Artikleid usundi- ja kombeloost 1. Tartu: Eesti Keele Instituut, lk 72-84 (http://www.folklore.ee/ rl/pubte/ee/sator/sator1/sator1-5.pdf - 12. oktoober 2006).

Relve, Hendrik 2004. Rändaja: Retki maailma põlislooduse ja -rahvaste juurde. Tallinn: Kunst.

Sarv, Tiina 2000. Kannatajad kahe ilma vahel. Postimees: Arter 18, 1. august (http:// arter.postimees.ee/leht/01/08/18e/lugu10.htm - 8. september).

Siimets, Ülo 1999a. Tšuktšid. Mäetagused: Hüperajakiri 11, lk 132-152 (http:// www.folklore.ee/tagused/nr11/tsukts.htm - 8. september 2006).

Siimets, Ülo 1999b. Tšuktšid II. Mäetagused: Hüperajakiri 12, lk 130-137 (http:// www.folklore.ee/tagused/nr12/tsukts.htm - 8. september 2006).

Sjomuškin, Tihhon 1953. Tšukotka. Tallinn: Eesti Riiklik Kirjastus.

Vääri, Eduard \& Kleis, Richard \& Silvet, Johannes (koost) 2000. Võõrsõnade leksikon. Tallinn: Valgus.

\section{Summary}

\section{On Shamanism and the Healing Rituals of Chukchi Shamans}

Ülo Siimets

Key words: Nganasans, reindeer herders, folk medicine, treatment session, shamanism, trance, Chukchi

The article attempts to answer the question "Who is a shaman?" on the basis of the available literature and the author's observations made during his 1971 trip to the land of the Chukchi. The article opens with an overview of materials published on the topic. Shamanism is one of the most intriguing and popular religious phenomena, mostly practised by indigenous peoples in North Siberia and North America. The shamans control spirits that reside in themselves and may distance themselves from the existing reality in order to travel or fly to other worlds. A shaman, who is conventionally a man, may consume hallucinogenic substances to perform rituals or alter the state of consciousness. The article concludes with a description of a healing session, carried out by Ejgeli, the shaman of the reindeer herding group, who successfully cured the injured foot of a teenage boy. 